\title{
THE LIFE-SAVING EFFECT OF HOSPITAL PROXIMITY
}

\author{
Pavla Bertoli \\ Veronica Grembi
}

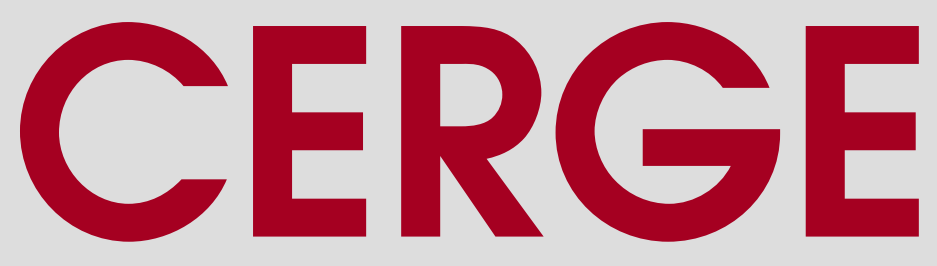

Charles University

Centerfor Economic Research and Graduate Education

Academy of Sciences of the Czech Republic

Economic Institute 


\title{
Working Paper Series \\ 565 (ISSN 1211-3298)
}

\section{The Life-saving Effect of Hospital Proximity}

\author{
Paola Bertoli \\ Veronica Grembi
}

\section{CERGE-EI}

Prague, May 2016 
ISBN 978-80-7343-372-7 (Univerzita Karlova v Praze, Centrum pro ekonomický výzkum a doktorské studium)

ISBN 978-80-7344-378-8 (Národohospodářský ústav AV ČR, v. v. i.) 


\title{
The Life-saving Effect of Hospital Proximity*
}

\author{
Paola Bertoli \\ University of Economics in Prague \\ CERGE-EI Affiliate Fellow ${ }^{\dagger}$
}

\author{
Veronica Grembi \\ Copenhagen Business School \\ Baffi Center, CEIS
}

\begin{abstract}
We provide a new assessment of the effect of hospital proximity in an emergency situation exploiting the exogenous variation in the proximity to cities that are legally allowed to have a hospital based on their population size. Based on Italian municipal data, our instrumental variable results show that a one-standarddeviation increase in the distance to the nearest hospital $(5 \mathrm{~km})$ raises the fatality rate by $13.84 \%$ at the sample average. This figure is equal to 0.92 additional deaths per 100 accidents. We show that both OLS and DD estimates, generally used in the literature, provide a downward-biased measure of the true effect of hospital proximity because they do not fully solve spatial sorting problems. Proximity is more important when the level of road safety is low, when emergency services are less responsive, and when the nearest hospital has relatively low quality standards.
\end{abstract}

JEL Classification: C26, I10, R41

Keywords: Access to Care, Hospital Proximity, Road-Traffic Accidents, Instrumental Variables, Difference in Differences

\footnotetext{
${ }^{*}$ We would like to thank seminar participants at the University of Economics in Prague, Copenhagen Business School, the University of Southern Denmark (COHERE), Copenhagen University, DIW Berlin, ZEW Mannheim, the 6th Petralia Sottana Applied Economics Workshop, the Spanish Association of Health Economics, the Workshop of Health Economics (Cambridge), and the Workshop of Health Economics (Copenhagen University) for their comments. We are grateful to Giacomo Calzolari, N. Meltem Daysal, Libor Dusek, Ronny Freier, Štěpán Jurajda, Toni Mora, Francesco Moscone, Tommaso Nannicini, Dario Pozzoli, Jonathan Skinner, and Mircea Trandafir for their useful suggestions.

${ }^{\dagger}$ CERGE-EI, a joint workplace of Charles University in Prague and the Economics Institute of the Czech Academy of Sciences, Politickych veznu 7, P.O. Box 882, 11121 Prague 1, Czech Republic.
} 


\section{Introduction}

In an emergency situation, being close to rather than far from a hospital can greatly affect the probability of survival. Although the importance of hospital proximity might be intuitive in many circumstances, assessing the overall costs of a change in the distance to a hospital facility has several empirical challenges. First, endogeneity problems arise when assessing the life-saving effect of hospital proximity using data on common life-threatening pathologies such as cardiac arrests or strokes.11 Hospital locations and quality are rarely random: compared to rural areas, urban areas are covered by more and better-quality hospitals. Likewise, people who are more likely to use healthcare services tend to live near hospitals rather than far from them, leading to the problem known as spatial sorting. Second, a variation in proximity can potentially generate both costs and benefits, and calculating this effect is not easy. For instance, when the increase in distance to the nearest hospital is due to hospital mergers, a benefit may arise because larger hospitals (i.e., high-volume-hospitals) can provide higher-quality services compared with the services of small hospitals (i.e., low-volume-hospitals) $!^{2}$

Although a proper cost-benefit analysis has not been implemented so far, the existing literature has addressed spatial sorting exploiting hospital closures, as they result in changes in hospital proximity. Papers using this identification strategy, which we define as the "closure approach", have shown that hospital proximity does reduce acute myocardial infarction (AMI) mortality rates (Buchmueller et al., 2006; Advic, 2014). Although the closure approach should be preferred over other approaches because it relies on stronger identifying assumptions than a basic OLS approach, it does not fully solve the spatial sorting problem. The approach assumes that closures are random, which is rarely the case in either public or private healthcare systems: smaller and less efficient hospitals are more often the target of closures (Lindrooth et al., 2003; Capps et al., 2010).

In this paper, we provide a new assessment of the life-saving effect of hospital proximity that differs from the existing literature in both the outcome used and the econometric identification strategy. Our outcome of interest is the fatality rate of road-traffic accidents (i.e., the number of deaths relative to the number of accidents) at the municipal level for nearly 8,000 Italian municipalities as recorded from 2000 to 2012. Road-traffic accidents represent an emergency situation (Pons et al., 2005) in which the patient cannot choose where she will be hospitalized, as the emergency service will make the de-

\footnotetext{
${ }^{1}$ According to the medical literature, the first 90 minutes are crucial to surviving cardiac arrest, and the 60 minutes after the first stroke symptoms are often called the golden hour (Saver et al., 2010).

${ }^{2}$ Additionally, the calculation of net benefits from the reallocation of facilities is complicated by the fact that new or remaining hospitals could register longer waiting lists depending on the new definition of the catchment area.
} 
cision on her behalf: $]^{3}$ Moreover, avoiding a specific cardiovascular pathology raises fewer concerns regarding spatial sorting (Bentham, 1986), although these concerns cannot be completely ruled out: for instance, if more severe accidents occur closer to hospitals, as shown in Section 4.3, then OLS estimates are biased. As a consequence, our contribution can be considered an improvement of the existing literature on the link between road-traffic accidents and proximity to an emergency care department (Brodsky and Hakkert, 1983; Bentham, 1986), which does not address the possible spatial sorting of accidents.

As a consequence of using road-traffic fatality rates as our outcome, our primary focus is the absolute distance to the nearest hospital, and we define proximity as this distance. Hence, our contribution also differs from the literature that exploits the differential distance between the nearest hospital and a hospital providing a specific treatment or characterized by a certain quality level to instrument for the probability of receiving a specific treatment/quality of care (e.g., McClellan et al., 1994; Kessler and McClellan 2000) or the role of proximity in the decision to be hospitalized in the first place (e.g., Daysal et al., 2015).

By contrast, we apply an instrumental variable (IV) approach to address the spatial sorting of accidents. Our identification exploits a population size requirement that has constrained the location of Italian hospitals since 1968. A 1968 law (n.132/1968) set the minimum population size required to open a new hospital at 25,000 residents. Hence, we instrument the distance to the nearest hospital between 2000 and 2012 using the distance to the nearest municipality that right after the 1968 law counted slightly more than 25,000 inhabitants. We use the population from the 1971 census, which is the first available census following the 1968 law, to identify those municipalities with more than 25,000 inhabitants as those most likely to have a hospital. As shown in Section 3, the population in 1971 is chosen, because the Italian healthcare system was officially inaugurated in 1978 and because it is also representative of the distribution of the census population around the 25,000 threshold in the 1981, 1991, and 2001 censuses.

Overall, our strategy exploits "selected" randomness in the geographical distribution of municipalities in 1971 to explain the life-saving effect of hospital proximity. In other words, we justify the randomness of the instrument with respect to road-traffic fatality rates by testing our model on different samples, as described in Section 3. Our sample selection is based on a simple intuition. Suppose that three municipalities counted fewer than 25,000 inhabitants in 1971, and hence, they are all less likely to have a hospital during our observational period (2000-2012). However, municipality one, which was

\footnotetext{
${ }^{3}$ In contrast to what happens in the US (Graves et al., 2015), patients in a public healthcare system are not allowed to direct the ambulance to a specific hospital, and the ambulance does not have the discretion to decide where to transport the patient. However, in the US, such discretion is also meant to be limited in an emergency situation.
} 
the nearest municipality counting more than 25,000 inhabitants in 1971, had 150,000 inhabitants, while municipalities two and three were located near municipalities with a 30,000 and 45,000 inhabitants, respectively. Because being near to a 150,000-inhabitant municipality in 1971 could directly affect road-traffic fatality rates in the present, for example, through levels of local development, ${ }^{4}$ we define our reference sample as including all municipalities that counted fewer than 25,000 inhabitants in 1971, that do not currently have a hospital, and for which the nearest municipality with more than 25,000 inhabitants in 1971 counted a maximum of 50,000 inhabitants. However, our results are robust to alternative definitions of the reference sample. Additionally, our results are robust to the use of a different way to measure proximity, using travel distance rather than Euclidean distance.

Our IV results show that a one-standard-deviation increase in the distance to the nearest hospital, equal to $5 \mathrm{~km}$, induces an increase of 0.92 percentage points in the road-traffic fatality rate ( $13.84 \%$ at the mean fatality rate). This figure is equivalent to an increase in the number of deaths by 0.92 per 100 accidents. Using a measure of the value of a statistical life (VSL) provided by the OECD (2012), we can assign a specific monetary value to the observed effect: decreasing hospital proximity by a standard deviation costs society 3.82 million euros per 100 accidents. In 2012, the EU counted 1,077,700 road-traffic accidents (EC, 2015), and the US had 5,615,000 police-reported accidents (NHTSA, 2014).

Comparing the IV results to the point estimates of both a basic ordinary least squares (OLS) and a difference-in-differences (DD) estimation, we show that both the OLS and DD estimates are downward biased. Using descriptive data from two Italian regions for which we have additional information on road-traffic accident types and the fatality rates for each accident type, we explain the downward bias in the OLS estimates as evidence of spatial sorting in the severity of accidents $5^{5}$ Our results show how an OLS model underestimates the actual effect of being near a hospital because the most severe accidents tend to occur in the proximity of a hospital.

We investigate three possible channels for the importance of proximity by exploiting differences in road safety captured by the North-South difference in the level of road safety, the characteristics of emergency services, and the characteristics of the nearest hospital. The analysis of channels indicates that proximity is more relevant when the level of road safety is low (i.e., more severe accidents); when emergency services are poorly equipped for rapid, effective interventions (i.e., low levels of radio coverage, low

\footnotetext{
${ }^{4}$ Although we control for elements correlated with local development, such as population density and income levels, some concerns may remain.

${ }^{5}$ This bias reconciles our findings with both the evidence from Yamashita and Kunkel (2010), who show that hospital proximity has no significant impact on heart disease mortality rates once the socioeconomic characteristics of patients are considered, and the evidence from Advic (2014), who assesses the impact of proximity only for the first year after a hospital closure.
} 
usage of helicopters and medical cars); and when the nearest hospitals are of low quality, as proxied by the various measures described in Sections 2.3 and 5.3.

Overall, the policy implications of our analysis should be viewed cautiously for at least two reasons. First, our focus is on the costs associated with decreased proximity in emergency situations. Results for non-emergency care might provide a different picture. In Appendix B, we test our models using a different outcome: maternal screenings for pregnant women. We find that although proximity is relevant to road-traffic fatalities, it does not robustly affect the incidence of maternal screenings. Therefore, the best response to a decrease in proximity might differ depending on the type of procedure and might require an overall evaluation. Second, consistent with the literature, a cost-benefit analysis of a change in proximity is beyond the scope of our work; as a consequence, we draw policy implications only on the basis of the cost analysis.

The remainder of the paper is organized as follows. Section 2 provides a basic overview of the institutional background and accounts for the data that we use. In Section 3, we define our identification strategy, and Section 4 presents the descriptive statistics and results. The analysis of the mechanisms behind the importance of proximity is provided in Section 5. Section 6 concludes the paper.

\section{Institutions and Data}

Designed in 1992 (i.e., DPR March 27, 1992), emergency care service in Italy consists of operative headquarters (Centrali Operative) organized on a provincial basis (Giorgetti, 2012).$^{6}$ The service receives emergency calls through a toll-free, 24-hour public first aid number (i.e., 118). The calls are managed by headquarters dispatchers, who coordinate the activities of emergency personnel. Headquarters dispatchers are a mix of trained responders and medical personnel (i.e., physicians). In particular, operative headquarters are responsible for activating the closest available ambulance and for identifying the closest emergency department.7 According to the 1992 legislation on emergency care, victims should receive proper hospital assistance within 20 minutes, at most, of being reached by the ambulance.

Between 2000 and 2012, 723 public hospitals were offering emergency care services $8^{8}$ Through information provided by the Ministry of Health, we geocoded their positions

\footnotetext{
${ }^{6}$ Italy counts almost 8,000 municipalities, 110 provinces and 20 regions. Before 1992, the emergency care network was operated by non-profit organizations responsible for ambulance services and by public hospitals. The system was quite decentralized and, in a way, similar to the US emergency service.

${ }^{7}$ Municipalities along regional borders can benefit from the assistance of hospitals just across the border when those hospitals are nearer than in-region hospitals. Our sample contains 414 municipalities for which the nearest hospital is in another region.

${ }^{8}$ Nearly all public hospitals offer emergency care, which is why we refer to hospital and emergency departments interchangeably. A few exceptions coincide with rehabilitation and/or geriatric facilities (i.e., 43 facilities). Private hospitals do not belong to the 24-hour public first aid service.
} 
and calculated the Distance for nearly 8,000 Italian municipalities. Distance is the Euclidean geographical distance from each municipality centroid to the centroid of the nearest municipality with a hospital $!^{9}$ Therefore, as a proxy for the travel distance to the nearest hospital, we use straight-line or "as the crow flies" distances. Because we lack specific information on accident locations, the use of the centroid is a reasonable approximation, especially when the reach of the municipality is small, as in the case of our subsamples. However, we could reasonably expect that the Euclidean distance between two centroids may differ from the actual travel distance (i.e., road distance), especially for mountain municipalities. Figure A1 in Appendix A provides an example of how the two measures can differ. Hence, we calculate the road travel distance using STATA and Google Geocoding by exploiting additional information on hospital addresses. First, addresses were geocoded via Google Geocoding API V3 using the user-written STATA program traveltime3.ado. The same STATA program was then used to calculate the actual road distance and driving time from each municipality centroid to the address of the closest hospital. This alternative measure of Distance has been computed for all municipalities and hospitals such that the robustness of the main results can also be tested using this measure of distance.

We merge the data on Distance with a set of data on road-traffic accidents, provinciallevel data on available emergency services, and data on hospital performance.

\section{$2.1 \quad$ Road-traffic Accident Data}

Given the lack of data at the accident level, we use the information collected by the police and processed by the National Institute of Statistics at the municipal level. Road-traffic accidents are recorded by place of occurrence rather than on the basis of the home municipality of the people involved in the accidents. This dataset provides information on the number of accidents and the number of deaths. Using these data, we construct our outcome of interest, Fatality, as the ratio between the number of deaths and the number of road-traffic accidents at the municipal level. Distinguishing between death before and death after hospitalization is not possible. Road-traffic fatalities are classified in only 2 categories: within the first 24 hours and within 30 days. The available data do not specify these two categories, but even with this additional information, we would not be able to identify deaths on impact. Therefore, our estimates should represent a lower bound of the true effect of proximity on fatality rates.

\footnotetext{
${ }^{9}$ Centroids are defined as the center of mass of a polygon within the polygon boundaries, and their coordinates are retrieved using a geographical information system (GIS). Based on a shape file containing polygons for all Italian municipalities, the latitude and longitude coordinates of centroids are calculated using a center-of-gravity-based algorithm. Next, we use these coordinates to compute the Euclidean geographical distance from each municipality centroid to the centroid of the closest municipality with a hospital.
} 


\subsection{Emergency Network Data}

Data on emergency services are useful to disentangle the channels that make hospital proximity more or less relevant. There are no yearly data on the characteristics of the Italian emergency care service, but in 2005, all headquarters participated in a survey administered by the Ministry of Health, which provides accurate information on the characteristics of the system on a certain date (Ministero della Salute, 2007). In 2005, 103 operative headquarters were managing calls through the 118 emergency number. Of the information available through the survey, we focus on four variables for which the response rate was $100 \%$.

The first is the extent of radio coverage. Radio frequencies are used for the communication between headquarters and ambulances throughout an emergency intervention. For instance, headquarters are informed about victims' conditions via radio, and via radio they direct ambulances to a hospital destination. Consequently, wider radio coverage ensures more reliable and extended communications between headquarters and ambulance staff. Second, we recover data on the number of helicopter interventions out of the total number of interventions per operative headquarters. Air medical services make it possible to reach and transport patients faster and provide a more stable ride with fewer accelerations/decelerations and less vibration. These services also allow staff to move patients from smaller or less well equipped hospitals to larger facilities once the patient is stabilized. In 2005, there were 44 helicopter rescue points. The third variable captures the prevalence of physicians among dispatchers at each headquarters. Differences in the level of medical knowledge of dispatchers could result in variation in the effectiveness of service. More highly trained dispatchers might be better skilled at obtaining crucial information from callers, evaluating the severity of injuries, and understanding the type of first intervention needed. Finally, we derive the incidence of medical cars per headquarters. This type of emergency vehicle is not designed to transport patients, but is meant to transport trained medical staff to the accident location. Medical cars allow doctors to treat/stabilize victims at the scene while waiting for an ambulance. Moreover, such vehicles may reduce response time because, for example, medical cars can move faster and more easily through bumpy and/or busy roads than full-sized ambulances can. The pictures in Figure A2 in Appendix A provide insight into the differences between an ambulance and a medical car.

\subsection{Hospital Data}

The structural characteristics of the nearest hospital, such as hospital size, hospital type (teaching vs. non-teaching), management, and performance indicators, might be important channels for understanding the role of hospital proximity. Because information on 
hospital characteristics such as the number of beds or wards is not available for the entire sample of hospitals, we recovered data on hospital volumes from the National Plan Outcomes (Piano Nazionale degli Esiti), a monitoring program operated by the Ministry of Health since 2007. In 2010, the plan held the most comprehensive set of information for 608 hospitals ${ }^{10}$ High volumes are negatively correlated with lower mortality rates per procedure (Luft et al.,1990). The intuition is that high-volume hospitals benefit from the learning by doing process while low-volume hospitals do not (Nuffield Institute for Health, 1996; Ho, 2000; Sound, 2010; Kristensen et al., 2014) ${ }^{11}$ Consequently, high-volume hospitals are considered higher-quality hospitals.

Among the different procedures monitored by the program, we collected volumes for the following: acute myocardial infarctions (AMI), strokes, non-oncological surgeries, and congestive heart failures (CHF). The first two were selected because they are primarily related to emergency services. Non-oncological surgeries and CHF help us to control for skills that could be useful to help the victim of a crash through an initial intervention. However, we do not use information on the volumes of each procedure individually because low volume for a single procedure may be not particularly informative in terms of expectations of overall quality (McClellan and Staiger, 1999). Therefore, we combine the information in a unique indicator representing the z-score average among all four z-score volume indices as in Bloom et al. (2015).

\section{Econometric Strategy}

We begin by estimating a basic OLS model in which distance to the nearest hospital, Distance, is our variable of interest, explaining variations in the fatality rates of roadtraffic accidents, Fatality, as described in Equation 1:

$$
\text { Fatality }_{m t}=\delta \text { Distance }_{m}+Z_{m}^{\prime} \sigma+X_{m t}^{\prime} \tau+\gamma_{h}+\pi_{p}+\beta_{t}+\epsilon_{m t}
$$

where $\gamma_{h}$ are the nearest hospital fixed effects, $\pi_{p}$ are provincial fixed effects, and $\beta_{t}$ are year fixed effects ${ }^{12}$ The provincial fixed effects account for the organization of the emergency operative headquarters, which are managed at the provincial level. The nearest hospital fixed effects allow us to control for differences in hospital characteristics,

\footnotetext{
${ }^{10}$ Data on mortality rates are not available for every hospital and are not risk adjusted to the hospital case mix (i.e., the type of patients treated). Beginning in 2011, risk-adjusted data are available for a low number of hospitals, and treatment volumes are no longer reported.

${ }^{11}$ However, the drivers of such correlation are not always clear. See Wang (2003).

${ }^{12}$ Both the nearest hospital fixed effects and the provincial fixed effects can be estimated because the nearest hospital is not necessarily located in the same province as municipality $m$. Our dataset contains 1,480 municipalities for which the nearest hospital is located in another province.
} 
such as their size, their managerial organization and, to some extent, their performance. Standard errors are clustered at the municipal level to address serial correlation problems. $Z_{m}^{\prime}$ and $X_{m t}^{\prime}$ are vectors of municipal characteristics that can affect the probability of having an accident and the speed with which first aid arrives. $Z_{m}^{\prime}$ includes a categorical variable for municipal altitude and a dummy for coastal municipalities. Conditional on distance, first aid could encounter greater difficulties in reaching an accident in a mountain municipality. Moreover, coastal municipalities implement special emergency plans for tourists because they experience a substantial increase in population during the spring-summer season. Finally, $X_{m t}^{\prime}$ includes population density and the yearly average income ${ }^{13}$ The average income approximates the financial resources available to municipal administrations through local taxation, with wealthier municipalities expected to have infrastructure systems that are in better condition (e.g., more street lighting, better road paving). Population density controls not only for the rapidity with which an injured person can receive assistance but also for the greater use of private transportation and a higher likelihood of road-related accidents being reported as we move from urban to rural areas (Clark and Cushing, 2004).

We expect that $\delta$ in Equation 1 is not correctly identified when using OLS whenever the type/severity of accidents is not randomly distributed across nearby hospitals. The use of controls for the emergency service (i.e., provincial fixed effects) and the characteristics of municipalities might not be sufficient to overcome spatial sorting problems. Consistent with previous works, we identify $\delta$ by modifying the model in Equation 1 as reported in Equation 2, which defines a DD approach. From 2000 to 2012, 29 hospitals were converted to rehabilitation centers and thus were considered closed as far as emergency services are concerned 14 Treated ${ }_{m}$ is a dummy variable equal to 1 if, for municipality $m$, the distance to the nearest hospital changed during our period of interest. In this specification, Distance changes at the municipal level according to the closure year 15

$$
\text { Fatality }_{m t}=\delta \text { Distance }_{m t}+\lambda \text { Treated }_{m}+Z_{m}^{\prime} \sigma+X_{m t}^{\prime} \tau+\gamma_{h}+\pi_{p}+\beta_{t}+\epsilon_{m t}
$$

However, even the DD approach does not completely eliminate concerns regarding

\footnotetext{
${ }^{13}$ For a better explanation of the variables, see Table A1 in Appendix A.

${ }^{14}$ Four hospitals were closed and 25 hospitals were converted into rehabilitation or geriatric structures, which do not have an emergency department. During the same period, 20 hospitals with an emergency department were opened, and among of these, 17 are located in a municipality with more than 25,000 inhabitants.

${ }^{15}$ Hence, Distance ${ }_{m t}=$ Distance $_{m}{ }^{*}$ After Treatment, with After Treatment $=1$ if $t \geq t_{0}$, with $t_{0}$ being the year of the structure's conversion to a rehabilitation center. In Equation 2, we also do not control for After Treatment because we are using year fixed effects.
} 
the correct identification of $\delta$ for at least three reasons. First, we know that the decision to close hospitals is not random. Generally, the targets for closure are hospitals that are smaller and less efficient, and have lower-quality standards. ${ }^{16}$ In addition, in public healthcare systems, electoral concerns can affect the decision to close a facility; see Bloom et al. (2015). Second, defining the exact time of a hospital closure is not always straightforward. A progressive closure of wards often occurs; while some are shut down, others remain operative. Hence, a sharp definition of closure can be problematic. Finally, as hospital closures are not a particularly common event, this approach relies on variations affecting only a very small proportion of observations. For instance, in our dataset, the DD exploits the changes in Distance for approximately $0.04 \%-0.03 \%$ of all municipalities.

To overcome endogeneity problems affecting both the basic OLS and the DD estimator, we exploit a 1968 Italian law that constrained the minimum population size required to open a new hospital to 25,000. Before that year, hospital locations reflected the location of care centers that had been in place since the beginning of the previous century and long before that time in larger cities. The 1968 legislation was intended to reorganize the entire healthcare system. The reorganization had three primary mechanisms: mergers of existing facilities, a set of rules for new facilities, and the acquisition of existing private facilities by the public healthcare system 17 The 1968 legislation is particularly important because it established the setting for the creation of a new national healthcare system, which was finally inaugurated in 1978. As a consequence, we use the distance from each municipality (centroid) to the nearest municipality (centroid) that counted more than 25,000 inhabitants in 1971 (i.e., the first census after 1968) as an instrument to measure the real effect of the distance to the nearest hospital on fatality rates ${ }^{18}$ Figure 1 shows the distributions of Distance and Distance 71.

Not every municipality above the 25,000 population threshold in 1971 had a hospital in 2000-2012. However, some municipalities below that threshold do have a hospital.

\footnotetext{
${ }^{16}$ For instance, a 2013 resolution by the Italian government sets the threshold for defining small hospitals that should be closed to 120 beds. The majority of European countries have repeatedly lowered the number of acute beds per 1,000 inhabitants to limit the number of hospitals (McKee, 2004; Busse et. al., 2001; Koppel et al., 2008).

${ }^{17}$ Before War War II, a systematic attempt to reorganize the healthcare system was conducted based on the Royal Decree of 30 September 1938, n.1631, and the Prime Minister Decree of 20 July 1939. For example, the location of hospitals was constrained to a set of specific criteria according to which the designated area had to be easily accessible.

${ }^{18}$ In Table A3, we provide descriptive evidence that municipalities in the 10,000-25,000 range in 1971 remain in the same population range in later census counts through 2001. Hence, the distribution of the population across the 25,000 threshold in 1971 remains stable in the following decades. Using the 1971 census also has the advantage of considering the long process often required when a new hospital needs to be opened. For instance, the plan to open of a hospital at Castelvetrano began in the 1970s, stopped during the 1980s, and then restarted, with the hospital opening in 1992. The speed of the authorization-construction process has not increased in recent times. Bargaining to open a new hospital in Padoa began in 2006. As of 2014, only bureaucratic papers had been filed, and construction has yet to begin.
} 
Figure 1: Distance Distribution

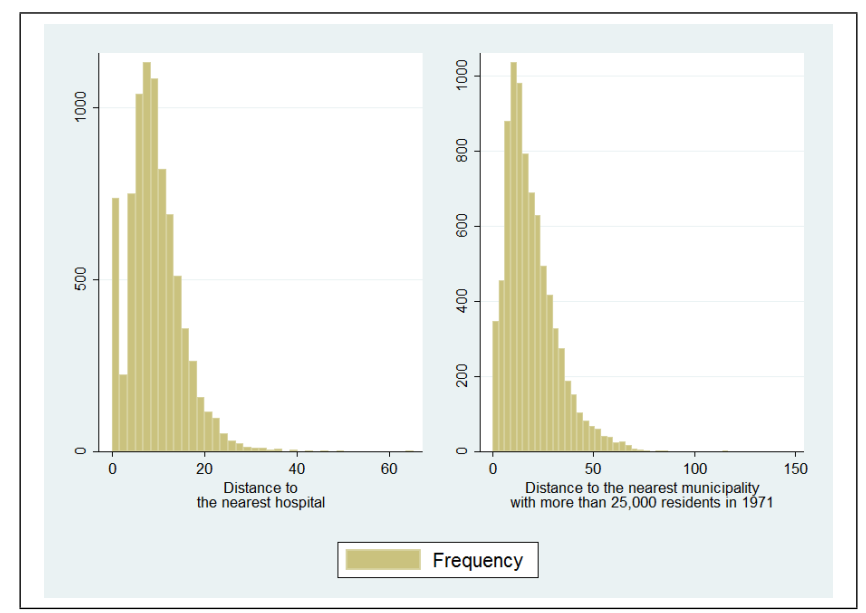

Notes: Distances are measured in kilometers from centroid to centroid. If the distance to the nearest hospital is equal to zero, then the municipality counts at least one hospital.

We estimate the effect of Distance on Fatality through two-stage least squares (2SLS) using Distance 71 as an instrument for Distance, and hence, the second- and first-stage equations are the following:

$$
\begin{gathered}
\text { Fatality }_{m t}=\alpha \text { Distance }_{m t}+Z_{m}^{\prime} \sigma+X_{m t}^{\prime} \tau+\gamma_{h}+\pi_{p}+\beta_{t}+\epsilon_{m t} \\
\text { Distance }_{m t}=\lambda \text { Distance } 71_{m}+Z_{m}^{\prime} \sigma+X_{m t}^{\prime} \tau+\gamma_{h}+\pi_{p}+\beta_{t}+v_{m t}
\end{gathered}
$$

To correctly identify the effect of Distance on Fatality, our instrument, Distance 71, must satisfy two conditions. First, the instrument must be highly correlated with the instrumented variable, Distance, which is easily verifiable through the first-stage statistics. Second, the instrument must affect Fatality only through Distance; it must be orthogonal to other unobservable characteristics. In other words, our identification relies on the randomness of the geographical distribution of municipalities in 1971 . We defend this untestable assumption by identifying the reference sample in different ways. The randomness of the instrument is more plausible when we compare municipalities that were close to centers just above 25,000 inhabitants in 1971, which is why we test our specifications with five differently specified samples.

The first sample includes all municipalities, as shown by the example in Panel (a) of Figure 2, which also displays the other four samples. We construct a second sample that includes all municipalities with fewer than 50,000 inhabitants in the 1971 census for which distance to the nearest hospital is different from zero, as these municipalities do not have a hospital. The aim is to exclude metropolitan areas and large cities that, in 
addition to having more and better hospital services, might also have better emergency response times. In the third sample, we exclude all municipalities for which Distance 71 is equal to zero and retain all municipalities with fewer than 25,000 inhabitants in the 1971 census. These municipalities are less likely to have a hospital on the basis of the 1968 reform. However, we might still be including municipalities located on the outskirts of large cities. All other things equal, being a municipality on the outskirts of Rome or Milan might have some effect on road-traffic fatality rates. Hence, we define the fourth sample as municipalities that had fewer than 25,000 inhabitants in 1971 and for which the nearest municipality had a population between 25,000 and 50,000 inhabitants. Finally, the fifth sample is the same as the fourth, except for the exclusion of those municipalities that have a hospital even if they had fewer than 25,000 inhabitants in 1971. The results from the fifth sample are our baseline specification.

\section{Figure 2: Samples}

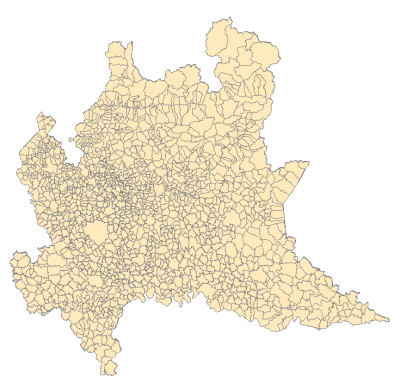

(a) 1

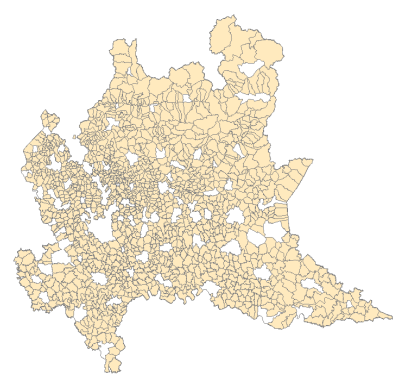

(b) 2

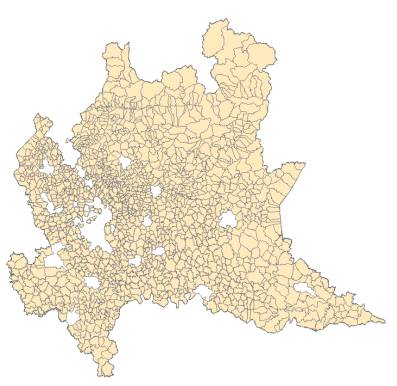

(c) 3

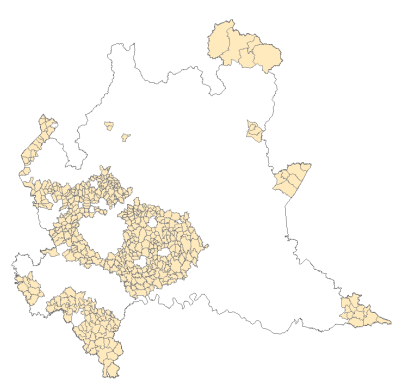

(d) 4

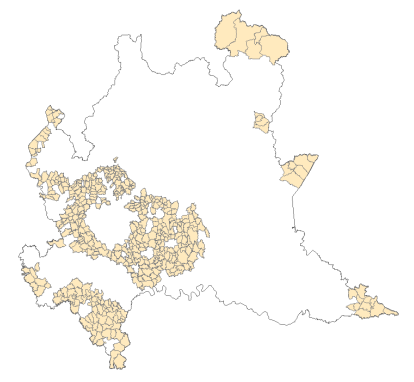

(e) 5

Notes: The figure provides an example of our different subsamples using the municipalities of Lombardia. (1) All Lombard municipalities. (2) Municipalities with fewer than 50,000 inhabitants and no hospital in 1971. (3) Municipalities with fewer than 25,000 inhabitants in 1971. (4) Municipalities close to a city with a population between 25,000 and 50,000 inhabitants and with fewer than 25,000 inhabitants in 1971. (5) Municipalities close to a city with a population between 25,000 and 50,000 inhabitants with fewer than 25,000 inhabitants and no hospital in 1971 . 


\section{Empirical Analysis}

\subsection{Descriptive Statistics}

As reported in Table 1, from 2000 to 2012, the overall average distance to the nearest hospital was equal to $8.56 \mathrm{~km}$, while the corresponding fatality rate was approximately 6 deaths for every 100 accidents (i.e., 6.046). In the fifth sample, these measures were slightly higher: 6.68 deaths for every 100 accidents, located $9.6 \mathrm{~km}$ from the nearest hospital on average. The increased distance is driven by the dropped municipalities with Distance equal to zero. Every subsample shows a positive correlation between Distance and Fatality, as clearly shown in Figure 3, where we plot the correlation between the distance to the nearest hospital and the fatality rate in an interval between 0 and 20 kilometers.

Table 1: Descriptive Statistics

\begin{tabular}{|c|c|c|c|c|c|}
\hline Variable & $\begin{array}{l}\text { All } \\
(1) \\
\end{array}$ & $\begin{array}{c}\text { No Hosp } \\
+ \text { Pop1971<50,000 } \\
(2) \\
\end{array}$ & $\begin{array}{c}\text { Pop1971<25,000 } \\
(3) \\
\end{array}$ & $\begin{array}{c}\text { Pop1971 }<\mathbf{2 5 , 0 0 0} \\
+ \text { Nearest }<50,000 \\
(4) \\
\end{array}$ & $\begin{array}{c}\text { Pop1971 }<25,000 \\
+ \text { Nearest }<50,000 \\
+ \text { No Hosp } \\
(5) \\
\end{array}$ \\
\hline Fatality Rate & $\begin{array}{c}6.046 \\
(17.408)\end{array}$ & $\begin{array}{c}6.357 \\
(18.153)\end{array}$ & $\begin{array}{c}6.236 \\
(17.794)\end{array}$ & $\begin{array}{c}6.519 \\
(18.521)\end{array}$ & $\begin{array}{c}6.687 \\
(19.094)\end{array}$ \\
\hline Distance & $\begin{array}{c}8.560 \\
(5.562)\end{array}$ & $\begin{array}{l}9.648 \\
(5.400)\end{array}$ & $\begin{array}{c}8.927 \\
(4.934)\end{array}$ & $\begin{array}{l}8.821 \\
(5.548)\end{array}$ & $\begin{array}{c}9.625 \\
(5.088)\end{array}$ \\
\hline Distance 1971 & $\begin{array}{c}18.471 \\
(12.350)\end{array}$ & $\begin{array}{c}17.621 \\
(11.982)\end{array}$ & $\begin{array}{c}18.106 \\
(12.007)\end{array}$ & $\begin{array}{c}17.717 \\
(12.033)\end{array}$ & $\begin{array}{c}17.457 \\
(11.978)\end{array}$ \\
\hline $\begin{array}{l}\text { Population } \\
\text { density }\end{array}$ & $\begin{array}{c}348.741 \\
(693.712)\end{array}$ & $\begin{array}{c}308.453 \\
(559.866)\end{array}$ & $\begin{array}{c}301.387 \\
(623.087)\end{array}$ & $\begin{array}{c}326.133 \\
(641.207)\end{array}$ & $\begin{array}{c}320.37 \\
(655.733)\end{array}$ \\
\hline Income & $\begin{array}{c}16,399 \\
(3,859.57)\end{array}$ & $\begin{array}{c}16,252.88 \\
(3,820.376)\end{array}$ & $\begin{array}{c}16,303 \\
(3,830.16)\end{array}$ & $\begin{array}{c}16,069 \\
(3,859.97)\end{array}$ & $\begin{array}{l}16,011.34 \\
(3,874.01)\end{array}$ \\
\hline Plains & $\begin{array}{c}54.501 \\
(49.797)\end{array}$ & $\begin{array}{c}54.182 \\
(49.871)\end{array}$ & $\begin{array}{c}53.59 \\
(49.825)\end{array}$ & $\begin{array}{c}56.124 \\
(49.624)\end{array}$ & $\begin{array}{c}56.607 \\
(49.562)\end{array}$ \\
\hline $\begin{array}{l}\text { Partially } \\
\text { mountainous }\end{array}$ & $\begin{array}{c}8.866 \\
(28.425)\end{array}$ & $\begin{array}{c}7.571 \\
(27.594)\end{array}$ & $\begin{array}{c}8.304 \\
(26.455)\end{array}$ & $\begin{array}{c}8.128 \\
(27.327)\end{array}$ & $\begin{array}{c}7.389 \\
(26.159)\end{array}$ \\
\hline $\begin{array}{l}\text { Totally } \\
\text { mountainous }\end{array}$ & $\begin{array}{c}36.634 \\
(48.181)\end{array}$ & $\begin{array}{c}38.246 \\
(48.599)\end{array}$ & $\begin{array}{c}38.106 \\
(48.565)\end{array}$ & $\begin{array}{c}35.748 \\
(47.926)\end{array}$ & $\begin{array}{c}36.004 \\
(48.002)\end{array}$ \\
\hline Coastal & $\begin{array}{c}9.291 \\
(29.03)\end{array}$ & $\begin{array}{c}7.469 \\
(26.289)\end{array}$ & $\begin{array}{c}8.093 \\
(27.273)\end{array}$ & $\begin{array}{c}9.734 \\
(29.642)\end{array}$ & $\begin{array}{c}8.971 \\
(28.577)\end{array}$ \\
\hline Observations & 81,212 & 71,900 & 77,473 & 42,296 & 38,790 \\
\hline Municipalities & 7,954 & 7,219 & 7,665 & 4,266 & 3,985 \\
\hline
\end{tabular}

Notes: Distance and Distance 1971 are in kilometers. For the overall sample, the average Distance in miles is 5.561 (sd 3.802 ), and the average for 1971 in miles is 11.840 (sd 7.118). Income is in per capita 2012 euros. 
Figure 3: Descriptive Evidence

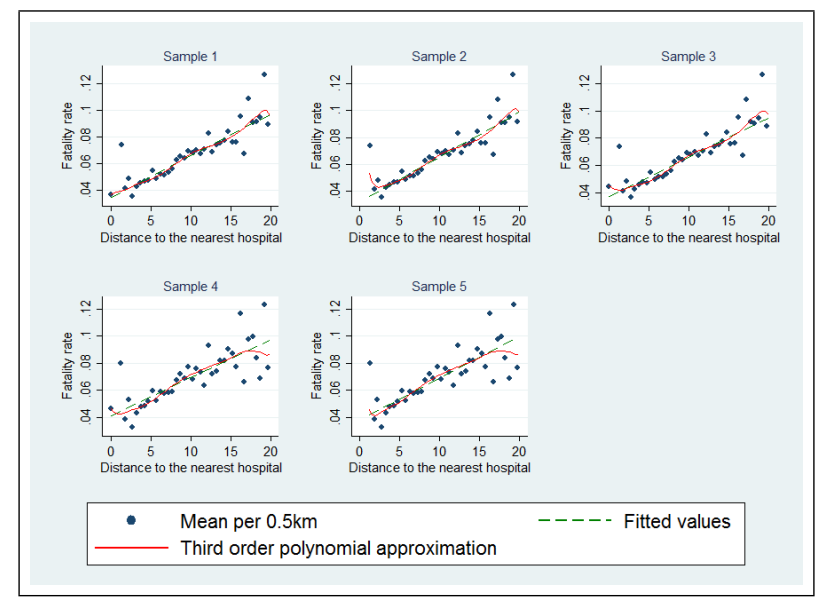

Notes: Sample 1: All Italian municipalities. Sample 2: Municipalities with fewer than 50,000 inhabitants and no hospital in 1971. Sample 3: Municipalities with fewer than 25,000 inhabitants in 1971. Sample 4: Municipalities with fewer than 25,000 inhabitants and close to a city with a population between 25,000 and 50,000 inhabitants in 1971. Sample 5: Municipalities close to a city with a population between 25,000 and 50,000 inhabitants with fewer than 25,000 inhabitants and no hospital in 1971 . The third-order polynomial approximation is a polynomial of the population of the nearest municipality that had at least 25,000 inhabitants in the 1971 census.

The majority of municipalities are in plains areas (54.5-56.6\%), and approximately $9 \%$ of them are coastal. The taxable income is substantially stable across all subsamples at slightly above 16,000 euros (2012 euros), whereas the population density ranges from 301 (sample 3) to 348 (sample 1) inhabitants per square kilometer.

\subsection{Results}

Tables 2, 3, and 4 show the results obtained using different methods 49 Table 4 also reports the evidence from the first stage, which highlights the strength of our instrument. The significance of the effect of hospital proximity on fatality rates is assessed by every method and in every sample. In addition to our coefficient of interest, we observe a negative relationship between population density and fatality rate, although the estimated effect is not significant in our reference sample. Our findings are consistent with the expectation that fatality rates are higher when a municipality is in a mountain region rather than on a plain. By contrast, fatality rates in coastal areas are lower, probably because of special arrangements concerning emergency interventions related to tourist seasons. Finally, fatality rates are significantly and negatively affected by income.

As stated, the results from the fifth sample are our baseline specification. Although the direction of the effect of Distance on Fatality is consistent across Tables (2)-(4), the magnitude of the effect changes from the OLS to the IV estimation, with the OLS coef-

\footnotetext{
${ }^{19}$ In Appendix A, Tables A4 and A5, we show the results without controls and without fixed effects.
} 
ficients being almost one-third of the IV coefficients. Based on Table 2, a 1-km increase in Distance induces a 0.057-percentage-point increase in Fatality, which is equivalent to an average increase of $0.85 \%$ at the mean of Fatality in the fifth sample. The DD results are similar: a 0.059-percentage-point increase per kilometer (i.e., $0.88 \%$ relative increase) and a 0.29-percentage-point increase (i.e., $4 \%$ relative increase in Fatality) when Distance increases by one standard deviation (i.e., $5 \mathrm{~km}$ ). The IV estimate yields different results. A $1-\mathrm{km}$ increase in Distance is equal to a 0.18 -percentage-point increase in Fatality, and a one-standard-deviation increase produces a relative increase of $13.8 \%$ in Fatality. After an increase of 6 kilometers, an additional death is registered every 100 accidents. Results are robust to the use of travel distance, as shown in Table A6.

Table 2: OLS Results: Fatality Rate

\begin{tabular}{|c|c|c|c|c|c|}
\hline Variable & $\begin{array}{l}\text { All } \\
\text { (1) }\end{array}$ & $\begin{array}{c}\text { No Hosp } \\
+ \text { Pop1971<50,000 } \\
(2)\end{array}$ & $\begin{array}{c}\text { Pop1971 }<25,000 \\
(3)\end{array}$ & $\begin{array}{c}\text { Pop1971 }<25,000 \\
+ \text { Nearest }<50,000 \\
(4)\end{array}$ & $\begin{array}{c}\text { Pop1971 }<\mathbf{2 5 , 0 0 0} \\
+ \text { Nearest }<50,000 \\
+ \text { No Hosp } \\
(5)\end{array}$ \\
\hline Distance & $\begin{array}{c}0.077990^{* * * *} \\
(0.011698)\end{array}$ & $\begin{array}{c}0.070972 * * * \\
(0.016457)\end{array}$ & $\begin{array}{c}0.080753^{* * *} \\
(0.012863)\end{array}$ & $\begin{array}{c}0.076237^{* * *} \\
(0.018938)\end{array}$ & $\begin{array}{c}0.057216^{* *} \\
(0.024741)\end{array}$ \\
\hline $\begin{array}{l}\text { Population } \\
\text { density }\end{array}$ & $\begin{array}{c}-0.000110 \\
(0.000069)\end{array}$ & $\begin{array}{c}-0.000332^{* * *} \\
(0.000090)\end{array}$ & $\begin{array}{c}-0.000347^{* * *} \\
(0.000104)\end{array}$ & $\begin{array}{l}-0.000157 \\
(0.000122)\end{array}$ & $\begin{array}{l}-0.000200 \\
(0.000129)\end{array}$ \\
\hline Income & $\begin{array}{c}-0.000204^{* * *} \\
(0.000030)\end{array}$ & $\begin{array}{c}-0.000226^{* * *} \\
(0.000034)\end{array}$ & $\begin{array}{c}-0.000223^{* * *} \\
(0.000032)\end{array}$ & $\begin{array}{c}-0.000222^{* * *} \\
(0.000048)\end{array}$ & $\begin{array}{c}-0.000219 * * * \\
(0.000051)\end{array}$ \\
\hline $\begin{array}{l}\text { Partially } \\
\text { mountainous }\end{array}$ & $\begin{array}{c}0.497835^{* *} \\
(0.247413)\end{array}$ & $\begin{array}{l}0.534799 * \\
(0.294881)\end{array}$ & $\begin{array}{l}0.493608^{*} \\
(0.267080)\end{array}$ & $\begin{array}{c}0.823569^{* *} \\
(0.411126)\end{array}$ & $\begin{array}{l}0.858038^{*} \\
(0.459074)\end{array}$ \\
\hline $\begin{array}{l}\text { Totally } \\
\text { mountainous }\end{array}$ & $\begin{array}{c}1.091789 * * * \\
(0.220196)\end{array}$ & $\begin{array}{c}1.156637^{* * * *} \\
(0.235409)\end{array}$ & $\begin{array}{c}1.034014^{* * *} \\
(0.226445)\end{array}$ & $\begin{array}{c}1.293337^{* * * *} \\
(0.335089)\end{array}$ & $\begin{array}{c}1.456345^{* * *} \\
(0.352876)\end{array}$ \\
\hline Coastal & $\begin{array}{c}-1.478114^{* * *} \\
(0.267865)\end{array}$ & $\begin{array}{c}-1.746598^{* * *} \\
(0.319496)\end{array}$ & $\begin{array}{c}-1.650995^{* * *} \\
(0.299875)\end{array}$ & $\begin{array}{c}-1.320412^{* * *} \\
(0.351364)\end{array}$ & $\begin{array}{c}-1.386560 * * * \\
(0.381325)\end{array}$ \\
\hline $\begin{array}{l}\text { Provincial FE } \\
\text { Year FE } \\
\text { Nearest Hosp FE }\end{array}$ & $\begin{array}{l}\text { Yes } \\
\text { Yes } \\
\text { Yes }\end{array}$ & $\begin{array}{l}\text { Yes } \\
\text { Yes } \\
\text { Yes }\end{array}$ & $\begin{array}{l}\text { Yes } \\
\text { Yes } \\
\text { Yes }\end{array}$ & $\begin{array}{l}\text { Yes } \\
\text { Yes } \\
\text { Yes }\end{array}$ & $\begin{array}{l}\text { Yes } \\
\text { Yes } \\
\text { Yes }\end{array}$ \\
\hline $\begin{array}{l}\text { Observations } \\
\text { Municipalities }\end{array}$ & $\begin{array}{c}81,212 \\
7,954\end{array}$ & $\begin{array}{l}71,900 \\
7,219\end{array}$ & $\begin{array}{c}77,473 \\
7,665\end{array}$ & $\begin{array}{c}42,296 \\
4,266\end{array}$ & $\begin{array}{c}38,790 \\
3,985\end{array}$ \\
\hline
\end{tabular}

Notes: All coefficients and standard errors are multiplied by 100. For the mountain dummies, Plain is the reference category. Robust standard errors are clustered at the municipal level in parentheses. Significance at the $10 \%$ level is represented by $*$, at the $5 \%$ level by $* *$, and at the $1 \%$ level by 
Table 3: Difference-in-Differences Results: Fatality Rate

\begin{tabular}{|c|c|c|c|c|c|}
\hline Variable & $\begin{array}{l}\text { All } \\
(1) \\
\end{array}$ & $\begin{array}{c}\text { No Hosp } \\
+ \text { Pop1971<50,000 } \\
(2) \\
\end{array}$ & $\begin{array}{c}\text { Pop1971 }<25,000 \\
(3) \\
\end{array}$ & $\begin{array}{c}\text { Pop1971<25,000 } \\
+ \text { Nearest }<50,000 \\
(4)\end{array}$ & $\begin{array}{c}\text { Pop1971 }<25,000 \\
+ \text { Nearest }<50,000 \\
+ \text { No Hosp } \\
(5) \\
\end{array}$ \\
\hline Distance & $\begin{array}{c}0.079230^{* * * *} \\
(0.013561)\end{array}$ & $\begin{array}{c}0.072979 * * * \\
(0.018959)\end{array}$ & $\begin{array}{c}0.082245^{* * *} \\
(0.014831)\end{array}$ & $\begin{array}{c}0.077153^{* * *} \\
(0.019911)\end{array}$ & $\begin{array}{c}0.059104^{* *} \\
(0.026893)\end{array}$ \\
\hline $\begin{array}{l}\text { Population } \\
\text { density }\end{array}$ & $\begin{array}{c}-0.000132^{*} \\
(0.000068)\end{array}$ & $\begin{array}{c}-0.000341^{* *} \\
(0.000134)\end{array}$ & $\begin{array}{c}-0.000364^{* * *} \\
(0.000137)\end{array}$ & $\begin{array}{l}-0.000184 \\
(0.000154)\end{array}$ & $\begin{array}{l}-0.000228 \\
(0.000159)\end{array}$ \\
\hline Income & $\begin{array}{c}-0.000198^{* * *} \\
(0.000039)\end{array}$ & $\begin{array}{c}-0.000220^{* * *} \\
(0.000044)\end{array}$ & $\begin{array}{c}-0.000218^{* * *} \\
(0.000041)\end{array}$ & $\begin{array}{c}-0.000220^{* * *} \\
(0.000067)\end{array}$ & $\begin{array}{c}-0.000216^{* * *} \\
(0.000071)\end{array}$ \\
\hline $\begin{array}{l}\text { Partially } \\
\text { mountainous }\end{array}$ & $\begin{array}{c}0.481324^{* *} \\
(0.239988)\end{array}$ & $\begin{array}{l}0.501509^{*} \\
(0.279715)\end{array}$ & $\begin{array}{l}0.476683^{*} \\
(0.250896)\end{array}$ & $\begin{array}{c}0.799039^{* *} \\
(0.394277)\end{array}$ & $\begin{array}{l}0.819138^{*} \\
(0.434629)\end{array}$ \\
\hline $\begin{array}{l}\text { Totally } \\
\text { mountainous }\end{array}$ & $\begin{array}{c}1.078415^{* * * *} \\
(0.224157)\end{array}$ & $\begin{array}{c}1.144031^{* * * *} \\
(0.237268)\end{array}$ & $\begin{array}{c}1.021295^{* * *} \\
(0.346643)\end{array}$ & $\begin{array}{c}1.195917^{* * * *} \\
(0.254357)\end{array}$ & $\begin{array}{c}1.342514^{* * *} \\
(0.367683)\end{array}$ \\
\hline Coastal & $\begin{array}{c}-1.509297^{* * *} \\
(0.415405)\end{array}$ & $\begin{array}{c}-1.738911^{* * *} \\
(0.430834)\end{array}$ & $\begin{array}{c}-1.649860^{* * *} \\
(0.435377)\end{array}$ & $\begin{array}{c}-1.336452^{* * *} \\
(0.493168)\end{array}$ & $\begin{array}{c}-1.403661^{* * *} \\
(0.475039)\end{array}$ \\
\hline Treated & $\begin{array}{c}0.357777 \\
(0.390480)\end{array}$ & $\begin{array}{c}0.283175 \\
(0.423886)\end{array}$ & $\begin{array}{c}0.340378 \\
(0.401121)\end{array}$ & $\begin{array}{l}-0.130186 \\
(0.594810)\end{array}$ & $\begin{array}{l}-0.211161 \\
(0.637461)\end{array}$ \\
\hline $\begin{array}{l}\text { Provincial FE } \\
\text { Year FE } \\
\text { Nearest Hosp FE }\end{array}$ & $\begin{array}{l}\text { Yes } \\
\text { Yes } \\
\text { Yes }\end{array}$ & $\begin{array}{l}\text { Yes } \\
\text { Yes } \\
\text { Yes }\end{array}$ & $\begin{array}{l}\text { Yes } \\
\text { Yes } \\
\text { Yes }\end{array}$ & $\begin{array}{l}\text { Yes } \\
\text { Yes } \\
\text { Yes }\end{array}$ & $\begin{array}{l}\text { Yes } \\
\text { Yes } \\
\text { Yes }\end{array}$ \\
\hline $\begin{array}{l}\text { Observations } \\
\text { Municipalities }\end{array}$ & $\begin{array}{c}81,212 \\
7,954\end{array}$ & $\begin{array}{l}71,900 \\
7,219\end{array}$ & $\begin{array}{c}77,473 \\
7,665\end{array}$ & $\begin{array}{c}42,296 \\
4,266\end{array}$ & $\begin{array}{c}38,790 \\
3,985\end{array}$ \\
\hline
\end{tabular}

Notes: Treated is a dummy equal to 1 if the municipality experienced an increase in Distance. All coefficients and standard errors are multiplied by 100 . For the mountain dummies, Plain is the reference category. Robust standard errors are clustered at the municipal level in parentheses. Significance at the $10 \%$ level is represented by $*$, at the $5 \%$ level by $* *$, and at the $1 \%$ level by $* * *$. 
Table 4: Results: IV

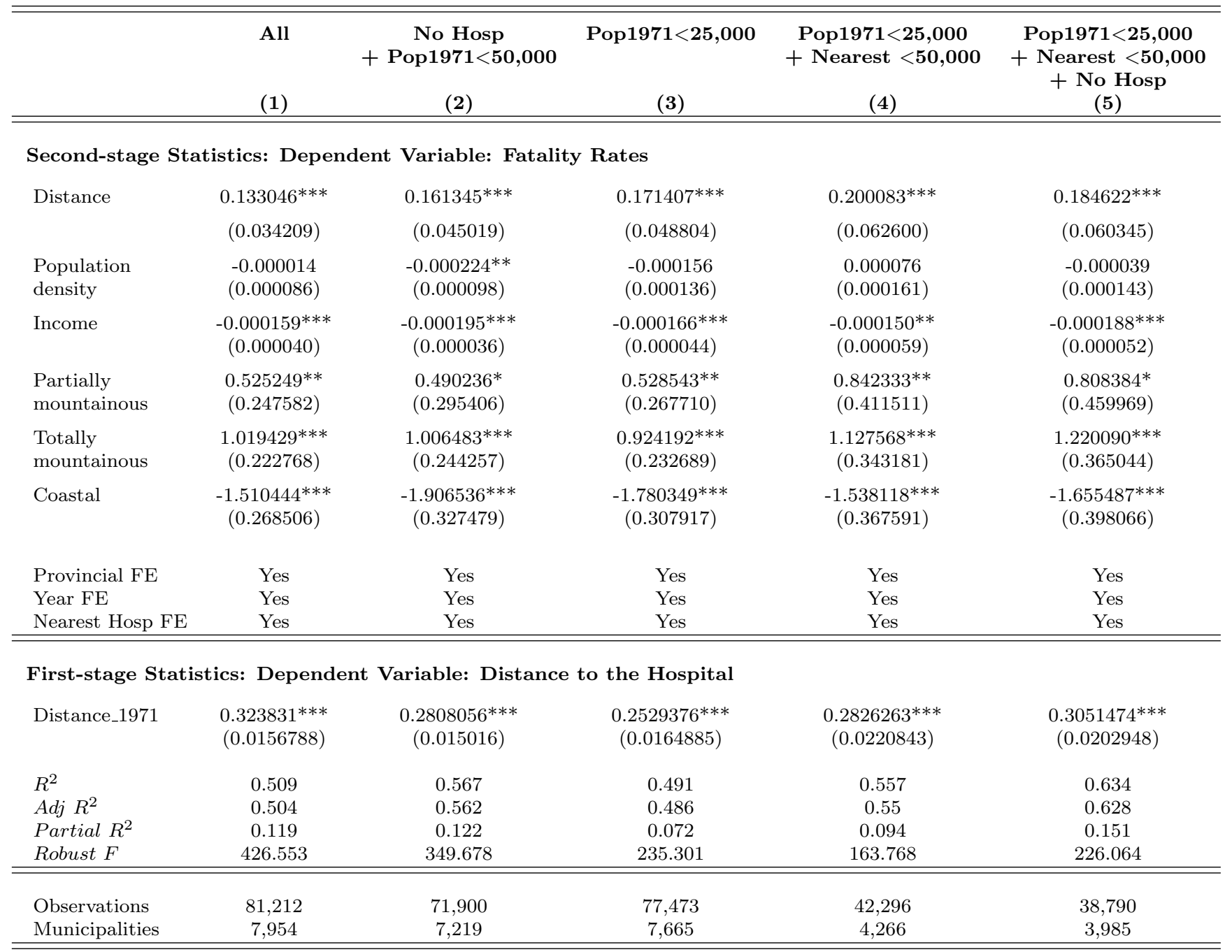

Notes: All coefficients and standard errors are multiplied by 100. For the mountain dummies, Plain is the reference category. Robust standard errors are clustered at the municipal level in parentheses. Significance at the $10 \%$ level is represented by $*$, at the $5 \%$ level by $* *$, and at the $1 \%$ level by $* * *$.

To better appreciate the practical implications of the estimated effects of hospital proximity, in Table 5, we present calculations for increases in distance to the nearest hospital of up to 30 kilometers. We also provide a travel time proxy for the increased distance based on three possible traveling speeds (i.e., 50, 70, and $90 \mathrm{~km} / \mathrm{h}$ ) ${ }^{20}$ A 5kilometer increase in Distance translates into 3 to 6 minutes of increased travel time, whereas an increase of 10 kilometers corresponds a travel time that is nearly 7 to 12 minutes longer. In addition to translating the results into relative increases in the fatality rate and additional deaths per 100 kilometers, we assign some monetary value to the additional loss of life using the value of a statistical life (VSL). The VSL measures

\footnotetext{
${ }^{20}$ Using data on Sweden, Petzäll et al. (2010) estimated the average speed of emergency transportation at $85.8 \mathrm{~km} / \mathrm{h}$. However, the actual speed depends on many factors, including traffic density, speed, and weather conditions. Therefore, providing a sharper translation of travel time is complicated.
} 
the tradeoff between wealth and fatality risk. This value represents the amount of money that society is willing to pay to avoid fatal risks as well as the amount of money that society is willing to accept to assume such risks. Despite its limitations, the VSL provides governments with a reference point for assessing the benefits of risk reduction efforts (Viscusi and Aldy, 2003, p.5) and is widely used in the evaluation of public policies such as environmental safety, road safety, and health regulations (Ashenfelter, 2006). This reference point should be considered a lower bound of the true costs of the loss of a human life because, by definition, it does not include the effects of the loss on the victim's relatives.

Several approaches can be used to quantify the VSL conditional on the policy evaluated (e.g., road safety vs. environmental issues), and estimates differ from country to country (Viscusi and Aldy, 2003). As a benchmark, we use the average EU-27 VSL as measured by the OECD (2012). This approach allows us to state that every additional kilometer costs 0.76 million euros per 100 accidents. A one-standard-deviation increase, 5 kilometers, will cost society 3.82 million euros per 100 accidents. Italy alone counted 188,228 road-traffic accidents in 2012. In the same year, the EU registered more than 1 million road-traffic accidents, and more than 5 million occurred in the US. 
Table 5: Simulated Effects of the IV Results

\begin{tabular}{|c|c|c|c|c|c|c|}
\hline \multirow{2}{*}{$\begin{array}{c}\text { Distance } \\
\text { hospital } \\
(\mathrm{km})\end{array}$} & \multicolumn{3}{|c|}{$\begin{array}{c}\text { Time } \\
\text { (minutes\&seconds) }\end{array}$} & \multirow[t]{2}{*}{$\begin{array}{c}\text { Fatality } \\
\text { Rate }(\%)\end{array}$} & \multirow[t]{2}{*}{$\begin{array}{l}\text { Extra Deaths } \\
\text { (100 accidents) }\end{array}$} & \multirow[t]{2}{*}{$\begin{array}{c}\text { VSL } \\
\text { (100 accidents mln euro) }\end{array}$} \\
\hline & $50 \mathrm{kmh}$ & $70 \mathrm{kmh}$ & $90 \mathrm{kmh}$ & & & \\
\hline 1 & 1.2 & 0.9 & 0.7 & 2.77 & 0.18 & 0.76 \\
\hline 2 & 2.4 & 1.7 & 1.3 & 5.54 & 0.37 & 1.53 \\
\hline 3 & 3.6 & 2.6 & 2.0 & 8.30 & 0.55 & 2.29 \\
\hline 4 & 4.8 & 3.4 & 2.7 & 11.07 & 0.74 & 3.06 \\
\hline 5 & 6.0 & 4.3 & 3.3 & 13.84 & 0.92 & 3.82 \\
\hline 6 & 7.2 & 5.1 & 4.0 & 16.61 & 1.11 & 4.59 \\
\hline 7 & 8.4 & 6.0 & 4.7 & 19.37 & 1.29 & 5.35 \\
\hline 8 & 9.6 & 6.8 & 5.3 & 22.14 & 1.48 & 6.11 \\
\hline 9 & 10.8 & 7.7 & 6.0 & 24.91 & 1.66 & 6.88 \\
\hline 10 & 12.0 & 8.6 & 6.7 & 27.68 & 1.85 & 7.64 \\
\hline 11 & 13.2 & 9.4 & 7.3 & 30.45 & 2.03 & 8.41 \\
\hline 12 & 14.4 & 10.3 & 8.0 & 33.21 & 2.22 & 9.17 \\
\hline 13 & 15.6 & 11.1 & 8.7 & 35.98 & 2.40 & 9.94 \\
\hline 14 & 16.8 & 12.0 & 9.3 & 38.75 & 2.59 & 10.70 \\
\hline 15 & 18.0 & 12.8 & 10.0 & 41.52 & 2.77 & 11.47 \\
\hline 16 & 19.2 & 13.7 & 10.7 & 44.28 & 2.96 & 12.23 \\
\hline 17 & 20.4 & 14.6 & 11.3 & 47.05 & 3.14 & 12.99 \\
\hline 18 & 21.6 & 15.4 & 12.0 & 49.82 & 3.33 & 13.76 \\
\hline 19 & 22.8 & 16.3 & 12.7 & 52.59 & 3.51 & 14.52 \\
\hline 20 & 24.0 & 17.1 & 13.3 & 55.36 & 3.70 & 15.29 \\
\hline 21 & 25.2 & 18.0 & 14.0 & 58.12 & 3.88 & 16.05 \\
\hline 22 & 26.4 & 18.8 & 14.7 & 60.89 & 4.07 & 16.82 \\
\hline 23 & 27.6 & 19.7 & 15.3 & 63.66 & 4.25 & 17.58 \\
\hline 24 & 28.8 & 20.6 & 16.0 & 66.43 & 4.44 & 18.35 \\
\hline 25 & 30.0 & 21.4 & 16.7 & 69.20 & 4.62 & 19.11 \\
\hline 26 & 31.2 & 22.3 & 17.3 & 71.96 & 4.81 & 19.87 \\
\hline 27 & 32.4 & 23.1 & 18.0 & 74.73 & 4.99 & 20.64 \\
\hline 28 & 33.6 & 24.0 & 18.7 & 77.50 & 5.18 & 21.43 \\
\hline 29 & 34.8 & 24.9 & 19.3 & 80.27 & 5.36 & 22.17 \\
\hline 30 & 36.0 & 25.7 & 20.0 & 83.03 & 5.55 & 22.93 \\
\hline
\end{tabular}

Notes: For these simulations, we use the coefficients in column (5) of Table 4 Fatality Rate=Number of deaths as a share of road-traffic accidents. $V S L=$ value of a statistical life; the reference value used is the average EU-27 value of statistical life as measured by OECD (2012), which amounts to 4,131,970 euros.

\subsection{Direction of the OLS Bias}

Our findings show that the OLS estimates are downward biased: the OLS results are lower bounds of the true effect. To provide insight into the negative OLS bias, we use municipal data from the Lombardy and Veneto regions. For these two regions, which account for 2,110 municipalities (26.10\% of all Italian municipalities), we were able to recover more information on the number of deaths per type of accident at the municipal level. Hence, we can derive the fatality rate for accidents that occurred over weekends, at night, in particular weather conditions, and on highways. ${ }^{21}$

\footnotetext{
${ }^{21}$ However, we cannot combine the information on the types of accidents. In other words, we can recover only the fatality rate over the weekend or at night, not over the weekend nights. Such detailed information is not publicly available at the municipal level. We can refer only to some aggregate statistics as reported in the text.
} 
Fatality rates might vary across different types of accidents in a systematic way: some accidents are more severe than others. For instance, according to the Italian National Institute of Statistics (ACI-ISTAT, 2013), the fatality rate is higher at night, largely because of greater infringement of speed limits. Between $9 \mathrm{pm}$ and $7 \mathrm{am}$, the fatality rate is higher than average, peaking around $5 \mathrm{am}$. At night during weekends, fewer but more severe accidents occur: $43 \%$ of nighttime accidents occur on Friday and Saturday nights, when the fatality rate is approximately $42 \%$ (ACI-ISTAT, 2010).

Although the highest number of road-traffic accidents tends to be reported on urban roads, the most severe accidents tend to occur on highways. For instance, in 2013, highways showed a higher fatality rate $(3.5 \%)$ than urban roads $(1.7 \%)$ (ACI-ISTAT, 2014). Highways are safer by design, but they are higher-risk roads because of the higher speed limits and the monotony of driving on them. Drivers' alertness and driving performance tend to decline in monotonous environments such as highways. Finally, weather conditions also appear to play a relevant role. Rain and snow are associated with only $11 \%$ of road-traffic fatalities, whereas the vast majority of deaths $(79 \%)$ are registered under good weather conditions (ACI-ISTAT, 2014). This tendency occurs because in better weather conditions, the level of attention decreases because drivers tend to underestimate the risk compared with, for instance, driving in fog.

We calculate the median distance (i.e., $6.58 \mathrm{~km}$ ) to the nearest hospital for municipalities in Lombardy and Veneto. We then seek to determine any systematic difference in the incidence of the most deadly types of accidents between municipalities located near (Proximity=1 when Distance is less than 6.58) and far from a hospital (Proximity=0). The intuition is that if the most deadly accidents tend to occur near a hospital, the true effect of hospital proximity is systematically underestimated using an OLS model, as proven by our results. If this occurs, then spatial sorting is occurring by accident type, which explains the downward bias of the OLS estimator. The setting is intuitive. Assume that two potential deadly accidents occur near a hospital, but only one results in a fatality because of hospital proximity. Far from the same hospital, two other accidents occur, one potentially deadly and the other not deadly. Because of the distance to the hospital, the outcome is one fatality. The final outcome is one death near the hospital and one far from it, with zero effect of proximity. However, the alternative of not having a hospital at all would have been two fatalities versus one fatality: the hospital actually decreased the fatality rate by half. The graphical analysis presented in Figure 4 using Lombardy and Veneto data confirms our insight.

The negative bias of the OLS estimates is important for two reasons. First, as already anticipated, it emphasizes the importance of addressing problems of spatial sorting when measuring the true effect of hospital proximity. Second, it increases the robustness of our identification, making the concerns regarding omitted variable bias less plausible. 
Figure 4: Types of Accidents

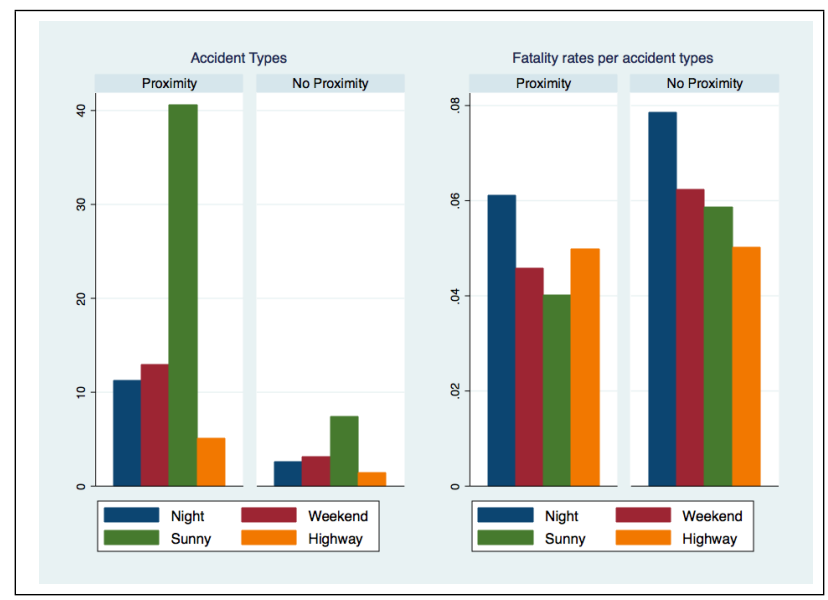

Notes: Road-traffic accidents between 2000 and 2012 at the municipal level for Lombardia and Veneto. Proximity is defined as being nearer than $6.58 \mathrm{~km}$ to a hospital and not proximity as being farther than $6.58 \mathrm{~km}$. $6.58 \mathrm{~km}$ is the median value of Distance for municipalities in Lombardia and Veneto. In Figure (A), the vertical axis represents the average number of accidents per type at the municipality level, while in Figure (B), the vertical axis is the municipal average ratio between the number of deaths per type and the number of accidents per type. T-tests for the significance of the differences between the two subsamples are statistically significant.

A hidden bias sensitivity analysis (Altonji et al., 2005) moves from the assumption that the OLS estimate is an upper bound of the true effect, which could eventually be equal to zero. Our findings show a different situation: the OLS is a lower bound of a true effect that could eventually be infinite.

\section{When Proximity Matters: More or Less}

If being near a hospital affects survival probability in the event of an emergency, factors that influence both the probability of accidents and the promptness of emergency response may increase or decrease the importance of hospital proximity. If emergency care services heavily rely on the use of helicopters, the actual distance may be less relevant in explaining variations in fatality rates. If the quality of the streets/infrastructure is particularly poor, then every additional kilometer between the accident location and the nearest hospital is expected to affect survival probability more severely than if the infrastructure is in good condition. Above all, we expect that the quality of the nearest hospital should trigger a heterogeneous response in the importance of hospital proximity.

Analyzing the mechanisms that make proximity more or less relevant has important policy implications. For instance, such an analysis might help to define where best to invest to decrease the impact of increased distance to the nearest hospital once the decision to close a hospital is made. For this reason, we analyze three sets of chan- 
nels. We first consider a generic approximation of the road safety level, then use the characteristics of the emergency care service, and finally focus on some proxies for the performance of the nearest hospitals. We generate dummies, $D$, for each characteristic and interact them with Distance using our IV approach to estimate the model. For each channel, we report the results for Distance in each subsample defined on $D$ and the significance of the difference between the two samples. This difference is robust to a full set of interactions of Distance with covariates at the municipality level (i.e., population density, average income, the categorical variable for the municipality's altitude, and the dummy for coastal municipalities). The aim is to exclude the possibility that the differential impact of Distance across samples is determined by other observable confounding characteristics of municipalities ${ }^{22}$ The results of this analysis are reported in Table 6 .

\footnotetext{
${ }^{22}$ The significance of the difference between the coefficients of Distance in the two subsamples is the parameter $\lambda$ of the following second-stage model for sample 5 , as defined in Section 3 :

$$
\begin{array}{r}
\text { Fatality }_{m t}=\text { SDistance }_{m}+\lambda D * \text { Distance }_{m}+\alpha D+ \\
Z_{m}^{\prime} \sigma+X_{m t}^{\prime}+\text { Distance }_{m} * Z_{m}^{\prime} \chi+\text { Distance }_{m} * X_{m t}^{\prime} \rho+\gamma_{h}+\pi_{p}+\beta_{t}+\epsilon_{m t}
\end{array}
$$

Where $D$ is the dummy for each channel. For instance, for the heterogeneity of North vs. South, $D=1$ if a municipality is located in the South. See Table A1 for a detailed explanation of each dummy used. Because we are dealing with two endogenous variables, we use two instruments to identify the effect of distance: Distance 71 and Distance $71^{*} \mathrm{D}$.
} 


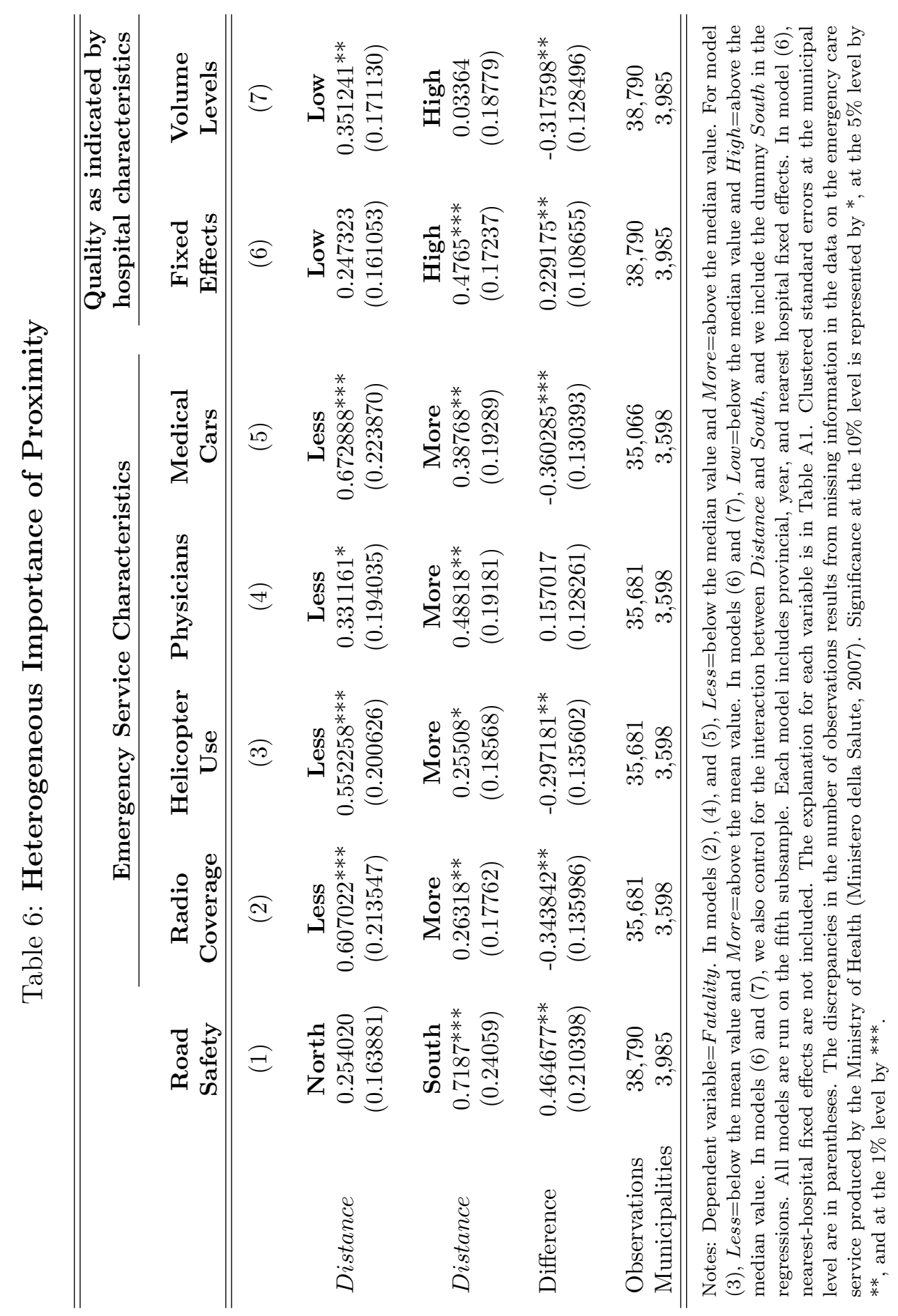




\subsection{Road Safety}

Broadly defined, road safety implies both good road conditions and cautious behavior on the part of drivers. The general condition of infrastructure is expected to play a role in providing first aid and in determining the severity of an accident. However, most severe accidents can also be associated with less-than-optimal enforcement mechanisms of road safety rules. As a consequence, drivers will adopt a suboptimal level of caution. We expect that more severe accident outcomes will be more affected by the distance to the nearest hospital. To investigate this channel, we exploit the differences between the North and South of Italy ${ }^{23}$ On the one hand, Southern municipalities are generally poorer, but we already account for this factor when controlling for the average income and its interaction with Distance. However, Southern municipalities are also known for their poor infrastructure level compared with their Northern counterparts. ${ }^{24}$ On the other hand, between 2009 and 2012, only $76 \%$ of Southern drivers regularly wore the front seat belt as opposed to $93 \%$ of Northern drivers. Similarly, the use of the rear seat belt is a regular habit for $34 \%$ of passengers in Northern regions but only $12.5 \%$ in Southern regions (Istituto Superiore della Sanitá, 2013).

Column (1) of Table 6 reports the value for the impact of Distance in the North and in the South as well as the differences between the two areas. Hospital proximity appears to be more relevant in the South than in the North, and the difference is statistically different from zero. Hence, adding an additional kilometer to the nearest hospital in the South increases the fatality rate by 0.71 percentage points. By contrast, in the North, this increase is equal to 0.25 percentage points, and the effect is not statistically significant. Therefore, investments in road maintenance and increased enforcement of traffic safety measures could partially counterbalance the negative impact of a decrease in hospital proximity.

\subsection{Emergency Service Characteristics}

We first exploit the geographical coverage of the radio system of each operative headquarters by dividing the sample at the median value of radio coverage, which is $80 \%$. As stated above, wider radio coverage is expected to guarantee a better emergency response. The results in Column (2) of Table 6 show that higher levels of radio coverage correspond to smaller effects of proximity. The difference is equal to 0.34 percentage points for each additional kilometer and is statistically significant. For the use of helicopter rescue, we refer to the mean value $(0.7 \%)$, as up to the 25 th percentile of the

\footnotetext{
${ }^{23}$ Differences between the Northern and Southern Regions are also explained in terms of social capital in Nannicini et al. (2013).

${ }^{24}$ There is considerable anecdotal evidence of the poor conditions of the streets in local newspapers in Southern regions.
} 
distribution of this variable is equal to zero. In the case of operative headquarters relying more on helicopter use, Column (3) provides evidence that proximity is less relevant ${ }^{25}$

More intense use of medical personnel, physicians (18\%), as dispatchers for the tollfree emergency number does not appear to provide any benefit in terms of reducing the importance of hospital proximity, as shown in Column (4). However, more intensive use of medical cars does provide a benefit, as reported in Column (5). Headquarters employing more than the median value of medical cars out of the total number of available vehicles (i.e., 12\%) experience a significant decrease in the importance of proximity by 0.36 percentage points per kilometer.

To compensate for the costs imposed on emergency situations when proximity varies, the optimal response could be investing in more effective organization for the emergency network, even with the use of the most advanced technologies (i.e., drones) ${ }^{26}$

\subsection{Nearest Hospital Characteristics}

The evidence indicates that every additional kilometer decreases the probability of survival because every additional kilometer will cause an injured individual to become a more serious case, as she will arrive at the hospital in worse condition as the time required to bring her there increases. Assessing whether proximity is more or less relevant conditional on the quality/performance of the nearest hospital is an empirical question. Ex ante, we face mixed predictions. On the one hand, we should expect that in an emergency situation, being near a high-quality hospital is more important than being near a low-quality hospital. If this assumption holds, then both high- and low-quality hospitals can equally incur savings from easy and serious cases, but on average, highquality hospitals tend to save more of both. In this case, fatality rates should increase the farther the accident victim is from a high-quality hospital. On the other hand, it is possible that serious cases are likely to be saved only at high-quality hospitals but have fewer or no chances at low-quality hospitals. ${ }^{27}$ In this case, every additional kilometer is more deadly if the nearest hospital is of low quality rather than high quality. The longer an accident victim must travel to a low-quality hospital, the lower her survival

\footnotetext{
${ }^{25}$ Because we control for the interactions between Distance and the mountain characteristics of municipalities as well as for the interaction with population density and income, the effect of helicopter use cannot be linked to these alternative explanations.

${ }^{26}$ The use of drones, for instance, decreases response times and can be helpful in precisely detecting the severity of emergencies and guiding first aid. At a cost of 15,000 euros each, the use of ambulance drones is the focus of the project Drones for Good developed by a graduate student at the Technical University of Delft IDE in the Netherlands. See https://www.youtube.com/watch?v=yrEI4bezWc. In Australia, a biannual competition is held under the name of Medical Express to foster the use of drones for rescue and medical purposes. For the 2015 competition, see http://www.uavoutbackchallenge.com.au.

${ }^{27}$ This point is similar to a discussion by McClellan and Staiger (1999) with reference to lower numbers of complications in low-quality hospitals. Because serious cases will die in low-quality hospitals, the survivors are better cases in which the incidence of complications is lower.
} 
probability is.

As we stated in Section 2.3, no comprehensive and case-mix adjusted quality indices exist for Italian hospitals. Hence, we use two measures to investigate the quality channel. First, we use the estimated fixed effects of the nearest hospitals from the second-stage results of our baseline specification. Although the fixed effects capture time-invariant hospital characteristics, we could regard them as a good approximation of a general combination of management, dimensions, and performance, which rarely undergo dramatic changes (McClellan and Staiger, 1999). Because they are derived from an equation explaining variations in fatality rates, greater fixed effects denote hospital characteristics that predict higher fatality rates. Second, we use the number of annually treated AMI, stroke, non-oncology surgeries, and CHF cases to approximate the volume level of a hospital by using 2010 data from the hospital evaluation program of the Ministry of Health (Ministro della Salute, 2013). We z-score the number of cases treated and then use the z-score of the average across all of them as an overall indicator of hospital quality (Bloom et al., 2015). The z-scored index has a mean of zero and a standard deviation of 1 .

Hence, we define low and high levels of fixed effects and low and high volumes with respect to the median values of the relative distributions. Low quality is expressed by large fixed effects and low volumes, while high quality is approximated by small fixed effects and high volumes. Columns (6) and (7) present the results. Proximity is more important when the nearest hospital reports larger fixed effects and lower overall activity levels. The two proxies go in the same direction: the distance to the worse hospitals has the greatest effects on survival probability. We interpret this result as evidence that low-quality hospitals tend to save more easy cases than difficult cases. As a consequence, to reduce the impact of proximity, investments in hospital quality are required.

\section{Conclusions}

We provide a new assessment of the impact of hospital proximity on accident victims' probability of survival in emergency situations using data on road-traffic accidents. To overcome spatial sorting problems resulting from non-random distributions of accident types around hospitals, we exploit a 1968 Italian law that mandated a population size of 25,000 inhabitants as a requirement to open a new hospital. The novelty of our approach is to identify the effect of proximity through the use of an IV approach. We instrument the hospital distance between 2000 and 2012 (i.e., our observation period) with distance to the nearest municipality satisfying the population requirement just after 1968. As such, our approach relies on the intention to treat, as we consider an institutional setting in which hospitals were also operating before 1968. Our analysis 
shows that a one-standard-deviation increase in the distance to the nearest hospital increases fatality rates by 0.92 percentage points ( $13.84 \%$ at the mean fatality rate). Our results are robust to several restrictions of the tested sample. The analysis of the mechanisms through which proximity affects road-traffic fatality rates shows that low levels of road safety, poor emergency care services, and low-quality hospitals increase the importance of hospital proximity. 


\section{References}

ACI-ISTAT, 2010. Rapporto sugli incidenti stradali 2009. Available at http://www . aci.it/laci/studi-e-ricerche/dati-e-statistiche/incidentalita.html.

ACI-ISTAT, 2013. Incidenti Stradali in Italia. Available at http://www.aci.it/ laci/studi-e-ricerche/dati-e-statistiche/incidentalita.html.

ACI-ISTAT, 2014. Incidenti Stradali in Italia. Available at http://www.istat.it/ it/archivio/137546.

Altonji, J. C., Elder, T. E., Taber, C. R. 2005. Selection on Observed and Unobserved Variables: Assessing the Effectiveness of Catholic Schools. Journal of Political Economy, 113: 151-184.

American Heart Association. 2014. Heart Disease and Stroke Statistics 2014. A Report From the American Heart Association. Available at http://circ.ahajournals.org.

Angrist, J., D. and Pischke, J.-S., 2008.Mostly harmless econometrics: An empiricist's companion. Princeton university press.

Ashenfelter, O., 2006. Measuring The Value Of A Statistical Life: Problems And Prospects. Economic Journal, 116(510,Mar): C10-C23.

Avdic, D., 2014. A Matter of Life and Death. Hospital Distance and Quality of Care: Evidence from Emergency Room Closures and Myocardial Infarctions. HEDG Working Paper 14/18.

Bentham, G., 1986. Proximity to hospital and mortality from motor vehicle traffic accidents. Social science \& medicine, 23(10): 1021-1026.

Bloom, N., Propper, C., Seiler, S., and J. Van Reenen. 2015. The Impact of Competition on Management Quality: Evidence from Public Hospitals. Review of Economic Studies 82(2): 457-489.

Brodsky, H. and A. S. Hakkert. 1983. Highway fatal accidents and accessibility of emergency medical services. Social Science \& Medicine, 17(11): 731-740.

Buchmueller, T. C., Jacobson, M., Wold, C. 2006. How Far from the Hospital? The Effect of Hospital closures on access to care. Journal of Health Economics, 25, pp. 740-761.

Busse, R., Petrakova, A. and R. Prymula. 2001. Implementing Hospital Reforms in the Czech Republic. Eurohealth, 7(3): 29-31.

Capps, C., Dranove, D. and R. C. Lindrooth. 2010. Hospital Closure and Economic Efficiency. Journal of Health Economics, 29, pp. 87-109.

Clark, D., E. and B. M. Cushing. 2004. Rural and Urban Traffic Fatalities, Vehicles Miles, and Population Density. Accident Analysis and Prevention 36: 967-972. 
Currie, J. and P. Reagan. 2003. Distance to hospital and children's use of preventive care: is being closer better and for whom? Economic Inquiry 41: 378-391.

Daysal, N.M., Trandafir, M. and R. van Ewijk. 2015. Saving Lives at Birth: The Impact of Home Births on Infant Outcomes. American Economic Journal: Applied Economics, forthcoming.

European Commission (EC), 2015. Statistics on Road Safety, available at: http:// ec.europa.eu/transport/road_safety/specialist/statistics/index_en.htm

Giorgetti, R., 2012. Legislazione ed Organizzazione del Servizio Sanitario. Maggioli Editore.

Measuring Returns to Hospital Care: Evidence from Ambulance Referral Patterns (with John Graves, Jonathan Gruber, and Samuel Kleiner) Journal of Political Economy. 123(1) February 2015: 170-214.

Ho, V., 2000. Evolution of the Volume-Outcome Relation for Hospitals Performing Coronary Angioplasty. Circulation, 101, pp. 1806-1811.

Istituto Superiore di Sanitá, 2013. La Sorveglianza Passi, available at: http://www . epicentro.iss.it/passi/dati/SicurezzaStradale.asp.

Kessler, D. P., and M. B. McClellan. 2000. Is Hospital Competition Socially Wasteful? The Quarterly Journal of Economics, 115(2): 577-615.

Koppel, A., Khur, K., Habicht, T., Saar, P., Habicht, J., and E. van Ginneken. 2008. Health Care Systems in Transition: Estonia, available at: http://www . euro. who. int/__data/assets/pdf_file/0011/80687/E91372.pdf.

Kristensen, P., Thillemann, T. and S.P. Johnsen. 2014. Is Bigger Always Better? A Nationwide Study of Hip Fracture Unit Volume, 30-Day Mortality, Quality of In-Hospital Care, and Length of Hospital Stay. Medical Care, 52(12): 1023-1029.

Lindrooth, R., C., Lo Sasso, A., T. and G. J. Bazzoli. 2003. The Effect of Urban Hospital Closures on Markets. Journal of Health Economics, 22, pp. 691-712.

Luft, H. S., Garnick, D. W., Mark, D. H., and S. J. McPhee. 1990. Hospital Volume, Physician Volume, and Patient Outcomes: Assessing the Evidence. Health Administration Publisher.

McClellan, M. and D. Staiger. 1999. The Quality of Health Care Providers. NBER Working Paper Series 7327.

McClellan, M., McNeil, B. J., and J. P. Newhouse. 1994. Does More Intensive Treatment of Acute Myocardial Infarction in the Elderly Reduce Mortality? JAMA, 272 , pp.859-866.

McKee, M., 2004. Reducing Hospital Beds: What are the Lessons to Be Learned?, available at: http://www.euro.who.int/_data/assets/pdf_file/0011/108843/ E85032.pdf. 
Ministero della Salute, 2013. Programma Nazionale Valutazione Esiti, available at: http://95.110.213.190/PNEed13/.

Ministero della Salute, 2007. Sistema di emergenza sanitaria territoriale 118. Direzione Generale della Programmazione sanitaria, livelli di assistenza e dei principi etici di sistema. Roma.

National Highway Traffic Safety Administration (NHTSA), (2014). Quick Facts 2012.

Nannicini, T., Stella, A., Tabellini, G., and U. Troiano, (2013). Social Capital and Political Accountability. American Economic Journal: Economic Policy 5: 222250.

Nuffield Institute for Health. 1996. Hospital Volume and Health care outcomes, costs and patient access. Effective Health Care 2(8): 1-16.

OECD, 2012. Mortality Risk Valuation in Environment, Health and Transport Policies. OECD Publishing.

Petzäll,K., Petzäll, J., Jansson, J, and G. Nordström. 2011. Time saved with high speed driving of ambulances. Accident Analysis and Prevention 43: 818-822.

Pons, P. T. , Haukoos, J., Bludworth, W., Cribley, T., Pons, K., and V. Markovchick. 2005. Paramedic Response Time: Does it Affect Patient Survival? Academic Emergency Medicine, 12(7): 595-600.

Saver, J.,L., Smith, E.,E., Fonarow, G.,C., Reeves, M.,J., Zhao, X., Olson, D.,M. and Schwamm, L.,H., 2010. GWTG-Stroke Steering Committee and Investigators. The golden hour and acute brain ischemia: presenting features and lytic therapy in ¿30,000 patients arriving within 60 minutes of stroke onset. Stroke, 41(7): 1431-1439.

Sound, R., 2010. Modeling the volume-effectiveness relationship in the case of hip fracture treatment in Finland. BMC Health Services Research, 10, pp. 238-250.

Viscusi, K. and J. E. Aldy. 2003. The Value of a Statistical Life: A Critical Review of Market Estimates Throughout the World. Journal of Risk and Uncertainty, 27 (1): 576 .

Wang, L. 2003. The Volume-Outcome Relationship: Busier Hospitals Are Indeed Better, But Why? Journal of the National Cancer Institute 95(10): 700-02.

Yamashita, T. and S. R. Kunkel. 2010. The Association between heart disease mortality and geographic access to hospitals: County Level comparison in Ohio, USA. Social Science and Medicine, 70, pp. 1211-1218. 


\section{Appendix A: Additional Figures and Tables}

Figure A1: Different Measures of Hospital Distance

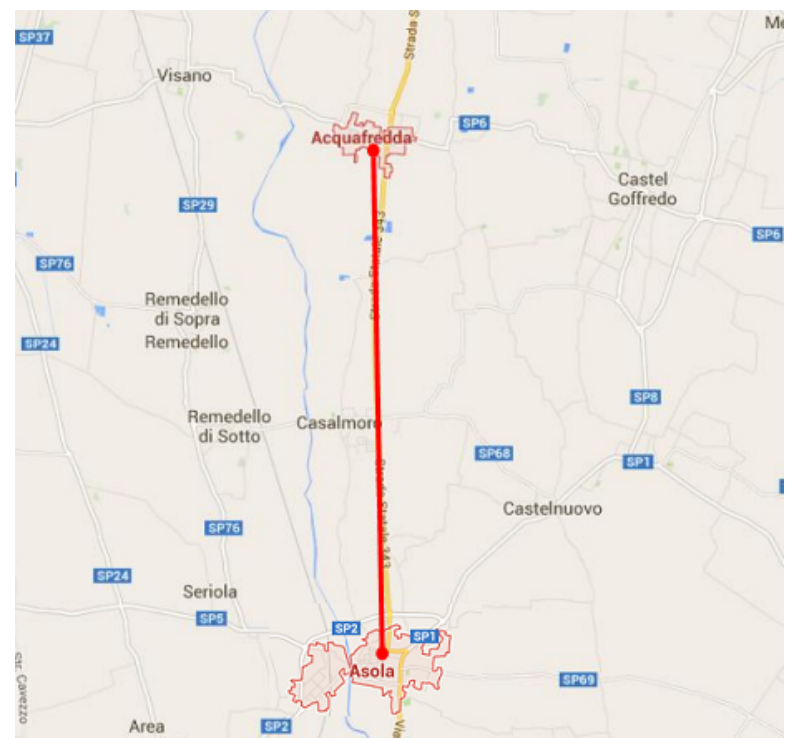

(a) Centroid-Centroid

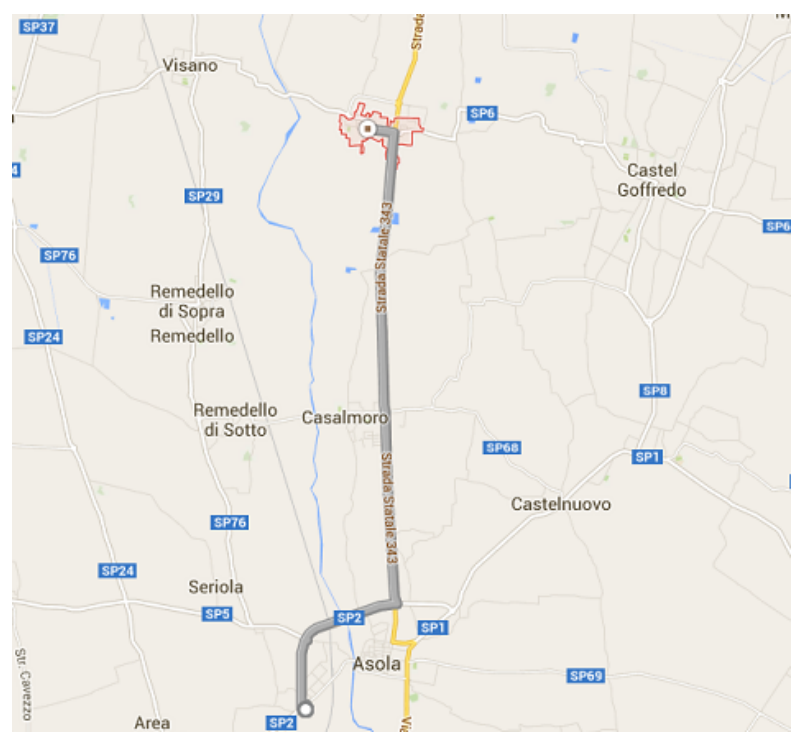

(b) Centroid-Hospital Address

Notes: The figures provide an example of the 2 possible approaches to calculating the distance to the nearest hospital. In Figure (a), we show distance to the nearest hospital as calculated from the centroid of each municipality to the centroid of the municipality of the nearest hospital. In Figure (b), we show distance to the nearest hospital computed using Google Maps, from the centroid of each municipality to the address of the nearest hospital. 
Figure A2: Ambulances and Medical Cars

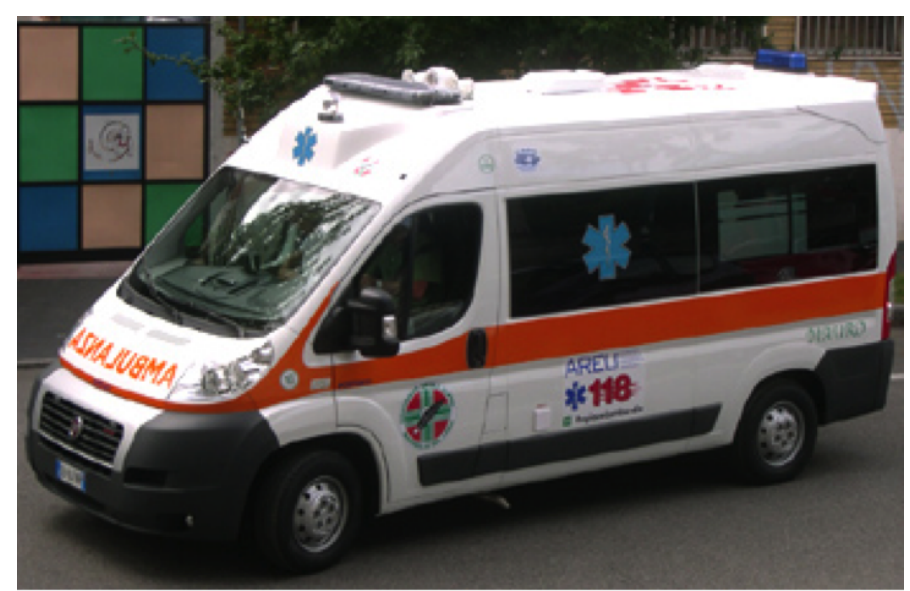

(a) Ambulance

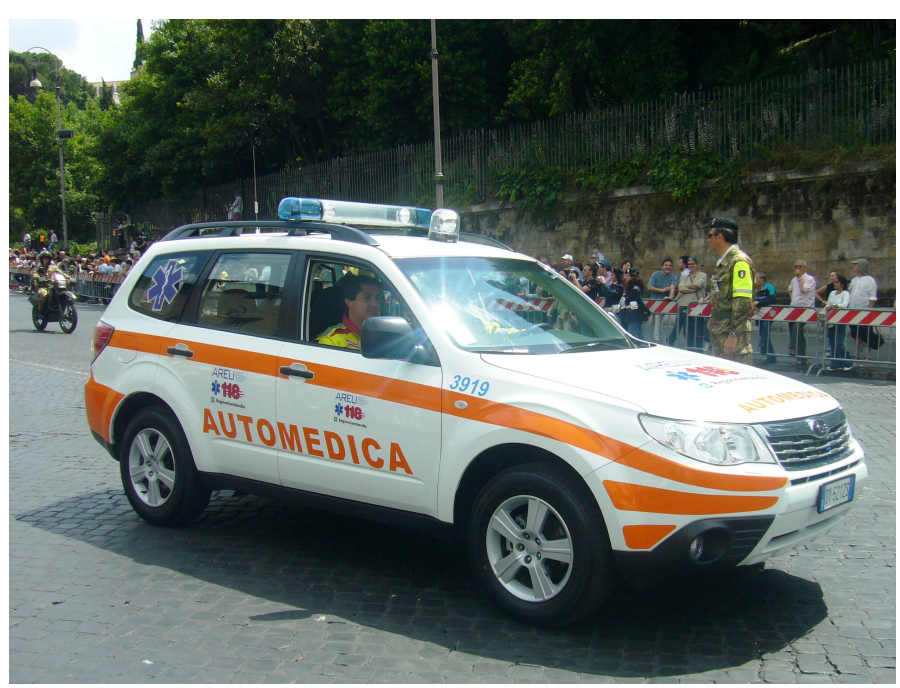

(b) Medical Car 
Table A1: Variable Definitions and Sources

\begin{tabular}{|c|c|c|c|}
\hline Variable & Type & Definition & Source \\
\hline Fatality Rate & Continuous & $\begin{array}{l}\text { Number of deaths out of } \\
\text { road-traffic accidents }\end{array}$ & ISTAT \\
\hline Distance & Continuous & $\begin{array}{l}\text { Distance in } \mathrm{km} \text { from the centroid of each } \\
\text { municipality to the centroid of the } \\
\text { nearest municipality with a hospital }\end{array}$ & $\begin{array}{l}\text { Our calculations } \\
\text { GIS* }\end{array}$ \\
\hline Distance 1971 & Continuous & $\begin{array}{l}\text { Distance in } \mathrm{km} \text { from the centroid of each } \\
\text { municipality to the centroid of the } \\
\text { nearest municipality with more than } \\
25,000 \text { inhabitants in the } 1971 \text { census }\end{array}$ & $\begin{array}{l}\text { Our calculations } \\
\text { GIS* } \\
1971 \text { census }\end{array}$ \\
\hline Population Density & Continuous & $\begin{array}{l}\text { Resident population out of } \\
\text { municipal extension in squared kilometers }\end{array}$ & ISTAT \\
\hline Income & Continuous & Per capita average taxable income in 2012 euros & $\mathrm{MoF}$ \\
\hline Plain & Dummy & $\begin{array}{l}\text { Equal to } 0 \text { if the municipality is defined as neither par- } \\
\text { tially mountainous nor totally mountainous }\end{array}$ & ISTAT \\
\hline Partial Mountain & Dummy & $\begin{array}{l}\text { Equal to } 1 \text { if the only part of the municipal territory } \\
\text { can be defined as totally mountainous }\end{array}$ & ISTAT \\
\hline Total Mountain & Dummy & $\begin{array}{l}\text { Equal to } 2 \text { if the municipality has } 80 \% \text { of its surface } \\
\text { above } 600 \mathrm{~m} \text { or a height difference greater than } 600 \mathrm{~m}\end{array}$ & ISTAT \\
\hline Coastal & Dummy & Equal to 1 if the municipal territory reaches the sea & ISTAT \\
\hline Value of Statistical Life & Continuous & $\begin{array}{l}\text { The amount of money in euros that society is } \\
\text { willing to pay to avoid the death of any individual }\end{array}$ & $\begin{array}{l}\text { Our calculations } \\
\text { OECD }(2012)^{* *}\end{array}$ \\
\hline Radio Coverage & Dummy & $\begin{array}{l}\text { Equal to } 1 \text { if the radio coverage of the operative head- } \\
\text { quarters is above the median value of the distribution }\end{array}$ & $\mathrm{MoH}$ \\
\hline Helicopter Use & Dummy & $\begin{array}{l}\text { Equal to } 1 \text { if the number of helicopter rescues by the } \\
\text { operative headquarters is above the mean value of the } \\
\text { distribution }\end{array}$ & $\mathrm{MoH}$ \\
\hline Physicians & Dummy & $\begin{array}{l}\text { Equal to } 1 \text { if the number of physicians working as dis- } \\
\text { patchers in the operative headquarters is above the me- } \\
\text { dian value of the distribution }\end{array}$ & $\mathrm{MoH}$ \\
\hline Medical Cars & Dummy & $\begin{array}{l}\text { Equal to } 1 \text { if the number of medical cars employed by } \\
\text { the operative headquarters is above the median value } \\
\text { of the distribution }\end{array}$ & $\mathrm{MoH}$ \\
\hline Volume Level & Dummy & $\begin{array}{l}\text { Equal to } 1 \text { if the activity volume level of the hospital } \\
\text { is above the median value of the distribution }\end{array}$ & $\mathrm{MoH}$ \\
\hline
\end{tabular}

Notes: $I S T A T=$ National Institute of Statistics; $M o F=$ Italian Ministry of Finance; $G I S=$ Geographic Information System $(*)=$ For each municipality polygon, we ask the GIS first to identify the coordinates of the related centroid and then to calculate the linear distance in kilometers between each municipality and every other municipality. Finally, for each municipality, we identify and retain the nearest city with a hospital, the nearest city with more than 25,000 inhabitants in the 1971 census and the related distances. $\left({ }^{* *}\right)=$ As a reference value for our calculations, we use the average EU-27 value of a statistical life as measured by OECD (2012), which corresponds to $4,141,970$ euros per individual. 
Table A2: Descriptive Statistics for Volumes

\begin{tabular}{lcc}
\hline \hline & \multicolumn{2}{c}{ Volume of Procedure } \\
\cline { 2 - 3 } & All & Sample 5 \\
\hline \hline \multirow{2}{*}{ AMI } & 117.58 & 98.74 \\
& $(128.84)$ & $(100.49)$ \\
\multirow{2}{*}{ Stroke } & 83.25 & 68.24 \\
& $(85.35)$ & $(61.32)$ \\
CHF & 185.27 & 165.64 \\
& $(156.31)$ & $(132.09)$ \\
Surgeries & 812.17 & 601.78 \\
& $(1033.14)$ & $(597.49)$ \\
\hline \hline
\end{tabular}

Notes: Mean values reported. Standard deviations in parentheses. $A M I$ : Acute myocardial infarction. $C H F$ : Congestive heart failure. Surgeries: non-oncology surgeries. Volume of Procedure refers to the number of events per procedure in 2010. Source: Ministry of Health (2007).

Table A3: Shifts Around the 25,000 Threshold

\begin{tabular}{lllll}
\hline \hline & & \multicolumn{3}{c}{ Population: 25,000-50,000 } \\
\cline { 3 - 5 } Population & Year & 1981 & 1991 & 2001 \\
& & & & \\
\hline \hline $\mathbf{1 0 , 0 0 0 -}$ & 1971 & None & None & None \\
$\mathbf{2 5 , 0 0 0}$ & $\mathbf{1 9 8 1}$ & & None & None \\
& 1991 & & & None \\
\hline \hline
\end{tabular}

Notes: This check indicates how many municipalities with 10,000 to 25,000 inhabitants in each census increased their population above 25,000 in the next census. 
Table A4: Results Without Controls

\begin{tabular}{|c|c|c|c|c|c|}
\hline Variable & $\begin{array}{l}\text { All } \\
(1) \\
\end{array}$ & $\begin{array}{c}\text { No Hosp } \\
+ \text { Pop1971<50,000 } \\
(2) \\
\end{array}$ & $\begin{array}{c}\text { Pop1971 }<25,000 \\
(3) \\
\end{array}$ & $\begin{array}{c}\text { Pop1971 }<25,000 \\
+ \text { Nearest }<50,000 \\
(4) \\
\end{array}$ & $\begin{array}{c}\text { Pop1971 }<25,000 \\
+ \text { Nearest }<50,000 \\
+ \text { No Hosp } \\
(5)\end{array}$ \\
\hline \multicolumn{6}{|l|}{ Panel A: OLS } \\
\hline Distance & $\begin{array}{c}0.114^{* * *} \\
(0.011)\end{array}$ & $\begin{array}{c}0.097^{* * *} \\
(0.016)\end{array}$ & $\begin{array}{c}0.097^{* * *} \\
(0.012)\end{array}$ & $\begin{array}{c}0.112^{* * *} \\
(0.018)\end{array}$ & $\begin{array}{c}0.077^{* * *} \\
(0.024)\end{array}$ \\
\hline \multicolumn{6}{|l|}{ Panel B: DD } \\
\hline Distance & $\begin{array}{c}0.219^{* * *} \\
(0.016)\end{array}$ & $\begin{array}{c}0.174^{* * *} \\
(0.024)\end{array}$ & $\begin{array}{c}0.193^{* * *} \\
(0.019)\end{array}$ & $\begin{array}{c}0.177^{* * *} \\
(0.023)\end{array}$ & $\begin{array}{c}0.126^{* * *} \\
(0.032)\end{array}$ \\
\hline \multicolumn{6}{|c|}{$\begin{array}{l}\text { Panel C: IV } \\
\text { Second-stage Statistic }\end{array}$} \\
\hline Distance & $\begin{array}{c}0.189^{* * *} \\
(0.027)\end{array}$ & $\begin{array}{c}0.218^{* * *} \\
(0.041)\end{array}$ & $\begin{array}{c}0.218^{* * *} \\
(0.041)\end{array}$ & $\begin{array}{c}0.226^{* * *} \\
(0.056)\end{array}$ & $\begin{array}{c}0.218^{* * *} \\
(0.056)\end{array}$ \\
\hline \multicolumn{6}{|c|}{ First-stage Statistics: Dependent Variable: Distance to the Hospital } \\
\hline Distance 1971 & $\begin{array}{c}0.394^{* * *} \\
(0.015)\end{array}$ & $\begin{array}{c}0.309^{* * *} \\
(0.015)\end{array}$ & $\begin{array}{c}0.299^{* * *} \\
(0.016)\end{array}$ & $\begin{array}{c}0.316^{* * *} \\
(0.022)\end{array}$ & $\begin{array}{c}0.328^{* * *} \\
(0.020)\end{array}$ \\
\hline$R^{2}$ & 0.462 & 0.554 & 0.453 & 0.526 & 0.623 \\
\hline $\operatorname{Adj} R^{2}$ & 0.456 & 0.549 & 0.448 & 0.519 & 0.617 \\
\hline Partial $R^{2}$ & 0.166 & 0.148 & 0.096 & 0.111 & 0.171 \\
\hline Robust F & 667.461 & 450.853 & 334.378 & 211.182 & 273.685 \\
\hline Provincial FE & Yes & Yes & Yes & Yes & Yes \\
\hline Year FE & Yes & Yes & Yes & Yes & Yes \\
\hline Nearest Hosp FE & Yes & Yes & Yes & Yes & Yes \\
\hline Observations & 81,212 & 71,900 & 77,473 & 42,296 & 38,790 \\
\hline Municipalities & 7,954 & 7,219 & 7,665 & 4,266 & 3,985 \\
\hline
\end{tabular}

Notes: All coefficients and standard errors are multiplied by 100. Robust standard errors are clustered at the municipal level in parentheses. Significance at the $10 \%$ level is represented by *, at the $5 \%$ level by ${ }^{* *}$, and at the $1 \%$ level by $* * *$. 
Table A5: Results Without Fixed Effects

\begin{tabular}{|c|c|c|c|c|c|}
\hline Variable & $\begin{array}{l}\text { All } \\
(1) \\
\end{array}$ & $\begin{array}{c}\text { No Hosp } \\
+ \text { Pop1971<50,000 } \\
(2) \\
\end{array}$ & $\begin{array}{c}\text { Pop1971<25,000 } \\
(3) \\
\end{array}$ & $\begin{array}{c}\text { Pop1971 }<25,000 \\
+ \text { Nearest }<50,000 \\
(4) \\
\end{array}$ & $\begin{array}{c}\text { Pop1971 }<25,000 \\
+ \text { Nearest }<50,000 \\
+ \text { No Hosp } \\
(5) \\
\end{array}$ \\
\hline \multicolumn{6}{|l|}{ Panel A: OLS } \\
\hline Distance & $\begin{array}{c}0.094^{* * *} \\
(0.010)\end{array}$ & $\begin{array}{c}0.085^{* * *} \\
(0.013)\end{array}$ & $\begin{array}{c}0.092^{* * *} \\
(0.010)\end{array}$ & $\begin{array}{c}0.079^{* * *} \\
(0.015)\end{array}$ & $\begin{array}{c}0.062^{* *} \\
(0.018)\end{array}$ \\
\hline \multicolumn{6}{|l|}{ Panel B: DD } \\
\hline Distance & $\begin{array}{c}0.181^{* * *} \\
(0.021)\end{array}$ & $\begin{array}{c}0.166^{* * *} \\
(0.023)\end{array}$ & $\begin{array}{c}0.174^{* * *} \\
(0.029)\end{array}$ & $\begin{array}{c}0.141^{* * *} \\
(0.028)\end{array}$ & $\begin{array}{c}0.134^{* * *} \\
(0.036)\end{array}$ \\
\hline \multicolumn{6}{|c|}{$\begin{array}{l}\text { Panel C: IV } \\
\text { Second-stage Statistics: Dependent Variable: Fatality Rates }\end{array}$} \\
\hline Distance & $\begin{array}{c}0.196^{* * *} \\
(0.045)\end{array}$ & $\begin{array}{c}0.195^{* * *} \\
(0.050)\end{array}$ & $\begin{array}{c}0.238^{* * *} \\
(0.069)\end{array}$ & $\begin{array}{c}0.345^{* * *} \\
(0.085)\end{array}$ & $\begin{array}{c}0.278^{* * *} \\
(0.064)\end{array}$ \\
\hline \multicolumn{6}{|c|}{ First-stage Statistics: Dependent Variable: Distance to the Hospital } \\
\hline Distance 1971 & $\begin{array}{c}0.106^{* * *} \\
(0.007)\end{array}$ & $\begin{array}{c}0.108^{* * *} \\
(0.016)\end{array}$ & $\begin{array}{c}0.075^{* * *} \\
(0.007)\end{array}$ & $\begin{array}{c}0.093^{* * *} \\
(0.010)\end{array}$ & $\begin{array}{c}0.125^{* * *} \\
(0.009)\end{array}$ \\
\hline$R^{2}$ & 0.190 & 0.215 & 0.154 & 0.188 & 0.274 \\
\hline $\operatorname{Adj} R^{2}$ & 0.190 & 0.215 & 0.154 & 0.188 & 0.274 \\
\hline Partial $R^{2}$ & 0.048 & 0.060 & 0.024 & 0.034 & 0.079 \\
\hline Robust F & 230.115 & 286.438 & 112.096 & 91.906 & 216.722 \\
\hline Observations & 81,212 & 71,900 & 77,473 & 42,296 & 38,790 \\
\hline Municipalities & 7,954 & 7,219 & 7,665 & 4,266 & 3,985 \\
\hline
\end{tabular}

Notes: All coefficients and standard errors are multiplied by 100. All regressions control for Population density, Income, and the mountain and coastal dummies. Robust standard errors are clustered at the municipal level in parentheses. Significance at the $10 \%$ level is represented by $*$, at the $5 \%$ level by **, and at the $1 \%$ level by $* * *$. 
Table A6: Results With Travel Distances

\begin{tabular}{|c|c|c|c|c|c|}
\hline Variable & $\begin{array}{l}\text { All } \\
(1) \\
\end{array}$ & $\begin{array}{c}\text { No Hosp } \\
+ \text { Pop1971<50,000 } \\
(2)\end{array}$ & $\begin{array}{c}\text { Pop1971<25,000 } \\
(3) \\
\end{array}$ & $\begin{array}{c}\text { Pop1971 }<25,000 \\
+ \text { Nearest }<50,000 \\
(4)\end{array}$ & $\begin{array}{c}\text { Pop1971 }<25,000 \\
+ \text { Nearest }<50,000 \\
+ \text { No Hosp } \\
(5)\end{array}$ \\
\hline \multicolumn{6}{|l|}{ Panel A: OLS } \\
\hline Distance & $\begin{array}{c}0.120^{* * *} \\
(0.012)\end{array}$ & $\begin{array}{c}0.101^{* * *} \\
(0.014)\end{array}$ & $\begin{array}{c}0.105^{* * *} \\
(0.013)\end{array}$ & $\begin{array}{c}0.090^{* * *} \\
(0.020)\end{array}$ & $\begin{array}{c}0.069^{* * *} \\
(0.022)\end{array}$ \\
\hline $\begin{array}{l}\text { Provincial FE } \\
\text { Year FE } \\
\text { Nearest Hosp FE }\end{array}$ & $\begin{array}{l}\text { Yes } \\
\text { Yes } \\
\text { Yes }\end{array}$ & $\begin{array}{l}\text { Yes } \\
\text { Yes } \\
\text { Yes }\end{array}$ & $\begin{array}{l}\text { Yes } \\
\text { Yes } \\
\text { Yes }\end{array}$ & $\begin{array}{l}\text { Yes } \\
\text { Yes } \\
\text { Yes }\end{array}$ & $\begin{array}{l}\text { Yes } \\
\text { Yes } \\
\text { Yes }\end{array}$ \\
\hline \multicolumn{6}{|l|}{ Panel B: DD } \\
\hline Distance & $\begin{array}{c}0.119^{* * *} \\
(0.014)\end{array}$ & $\begin{array}{c}0.099^{* * *} \\
(0.015)\end{array}$ & $\begin{array}{c}0.010 * * * \\
(0.015)\end{array}$ & $\begin{array}{c}0.087^{* * *} \\
(0.020)\end{array}$ & $\begin{array}{c}0.066^{* * *} * \\
(0.022)\end{array}$ \\
\hline $\begin{array}{l}\text { Provincial FE } \\
\text { Year FE } \\
\text { Nearest Hosp FE }\end{array}$ & $\begin{array}{l}\text { Yes } \\
\text { Yes } \\
\text { Yes }\end{array}$ & $\begin{array}{l}\text { Yes } \\
\text { Yes } \\
\text { Yes }\end{array}$ & $\begin{array}{l}\text { Yes } \\
\text { Yes } \\
\text { Yes }\end{array}$ & $\begin{array}{l}\text { Yes } \\
\text { Yes } \\
\text { Yes }\end{array}$ & $\begin{array}{l}\text { Yes } \\
\text { Yes } \\
\text { Yes }\end{array}$ \\
\hline
\end{tabular}

Panel C: IV

Second-stage Statistics: Dependent Variable: Fatality Rates

\begin{tabular}{|c|c|c|c|c|c|}
\hline Distance & $\begin{array}{c}0.247^{* * *} \\
(0.042)\end{array}$ & $\begin{array}{c}0.203^{* * *} \\
(0.049)\end{array}$ & $\begin{array}{c}0.208^{* * *} \\
(0.054)\end{array}$ & $\begin{array}{c}0.161^{* * *} \\
(0.070)\end{array}$ & $\begin{array}{c}0.156^{* * *} \\
(0.069)\end{array}$ \\
\hline $\begin{array}{l}\text { Provincial FE } \\
\text { Year FE } \\
\text { Nearest Hosp FE }\end{array}$ & $\begin{array}{l}\text { Yes } \\
\text { Yes } \\
\text { Yes }\end{array}$ & $\begin{array}{l}\text { Yes } \\
\text { Yes } \\
\text { Yes }\end{array}$ & $\begin{array}{l}\text { Yes } \\
\text { Yes } \\
\text { Yes }\end{array}$ & $\begin{array}{l}\text { Yes } \\
\text { Yes } \\
\text { Yes }\end{array}$ & $\begin{array}{l}\text { Yes } \\
\text { Yes } \\
\text { Yes }\end{array}$ \\
\hline \multicolumn{6}{|c|}{ First-stage Statistics: Dependent Variable: Distance to the Hospital } \\
\hline Distance_1971 & $\begin{array}{c}0.394^{* * *} \\
(0.023)\end{array}$ & $\begin{array}{c}0.373^{* * *} \\
(0.23)\end{array}$ & $\begin{array}{c}0.337^{* * *} \\
(0.024)\end{array}$ & $\begin{array}{c}0.360 * * * \\
(0.0033)\end{array}$ & $\begin{array}{c}0.378^{* * *} \\
(0.031)\end{array}$ \\
\hline $\begin{array}{l}R^{2} \\
\text { Adj } R^{2} \\
\text { Partial } R^{2} \\
\text { Robust } F\end{array}$ & $\begin{array}{c}0.504 \\
0.499 \\
0.084 \\
298.471 \\
\end{array}$ & $\begin{array}{c}0.533 \\
0.528 \\
0.082 \\
254.254 \\
\end{array}$ & $\begin{array}{c}0.490 \\
0.484 \\
0.057 \\
185.148 \\
\end{array}$ & $\begin{array}{c}0.588 \\
0.582 \\
0.067 \\
120.638 \\
\end{array}$ & $\begin{array}{c}0.635 \\
0.629 \\
0.088 \\
148.11\end{array}$ \\
\hline $\begin{array}{l}\text { Observations } \\
\text { Municipalities }\end{array}$ & $\begin{array}{c}80,693 \\
7,901\end{array}$ & $\begin{array}{c}71,879 \\
7,207\end{array}$ & $\begin{array}{c}76,967 \\
7,613\end{array}$ & $\begin{array}{c}41,882 \\
4,224\end{array}$ & $\begin{array}{c}38,605 \\
3,962\end{array}$ \\
\hline
\end{tabular}

Notes: All coefficients and standard errors are multiplied by 100. All regressions control for Population density, Income, and the mountain and coastal dummies. Robust standard errors are clustered at the municipal level in parentheses. Significance at the $10 \%$ level is represented by $*$, at the $5 \%$ level by ${ }^{* *}$, and at the $1 \%$ level by $* * *$. 


\section{Appendix B: Alternative Outcome: Maternal Screenings}

In this appendix, we consider an alternative outcome to assess the importance of hospital proximity: maternal screenings. We choose maternal screenings for three reasons. First, pregnancy is a condition distributed across the entire country, and every hospital can perform these screenings. Second, in Italy, an average of $88 \%$ of deliveries occur in public hospitals (Ministero della Salute, 2011). Hence, the sole use of data on public hospital locations should not raise any concerns, given the importance of public hospitals with respect to deliveries ${ }^{28}$ Third, out-of-region mobility is expected to be low in these tests. ${ }^{29}$ Conversely, we believe that both the presence of private hospitals and mobility could constitute important issues in analyzing cancer-related pathologies.

As proximity affects survival probabilities in the event of an emergency, it might affect non-emergency care to a lesser extent. The available evidence on the role of hospital proximity in non-emergency care presents mixed results. Buchmueller et al. (2006) find no effects of hospital closure on cancer screenings and mortality due to cancer. This result is partially different from the finding of Currie and Reagan (2003) on the incidence of hospital proximity in children's checkups. Using survey data from the US, the authors find that a 1.6-kilometer (1-mile) increase lowers the probability of having a checkup by 3 percentage points, albeit the effect is significant only for inner-city black children. However, their model does not exploit any exogenous variation.

For the analysis in this appendix, we use patients' discharge records provided by the Italian Ministry of Health. We generate two measures of interest that represent ratios at the year/municipal level and are calculated as a share of the total number of deliveries at the year/municipal level. The first measure, Screening, includes all medical checks and tests related to pregnancy. Therefore, this measure refers to tests that can be performed before or after delivery (e.g., antenatal screenings, supervision of normal and high-risk pregnancy, general postpartum tests, and postpartum tests of breastfeeding mothers) ${ }^{30}$ The second measure, Routine Screenings, includes all routine pregnancy tests. This measure thus differs from Screening because it ignores the supervision of high-risk pregnancies as well as antenatal and postpartum screenings 31 The use of patients' discharge records requires a warning. Because discharge records imply that patients are hospitalized, we are considering women who must be hospitalized to take the screening. This explains the low incidence of our measures in the population of pregnant women. However, this aspect is also the most interesting element of our data. Conditional on requiring additional care beyond a basic pregnancy, does hospital proximity play any role?

We exploit the same identification presented in Section 3 of the main text to identify the effect of proximity on maternal screenings. While the reduced form and the first stage are described by Equations 3 and 4 , we add a new vector of controls to the

\footnotetext{
${ }^{28}$ Several regions have $100 \%$ of deliveries in public hospitals, as they do not reimburse deliveries in private facilities.

${ }^{29}$ Within the National Healthcare System, patients are assigned to a public hospital based on their municipality of residence. Nevertheless, they are free to choose a different hospital for treatment unless it is an emergency. In emergency situations, the hospital is determined by the location of the emergency.

${ }^{30}$ We refer to ICDM codes from V22 to V242, from V262 to V264 (excluding V2622), and from V28 to V289 for diagnosis.

${ }^{31}$ We refer to ICDM codes from V22 to V222 for diagnosis.
} 
specifications on maternal screenings, which includes the following variables at the municipal/year level: the incidence of married marital status (Married), the incidence of Italian nationality (Italian), and the average age of pregnant women (Age). Descriptive statistics for these variable are reported in Table B1.

As presented in Tables B2 and B3, the results for both outcomes show that hospital proximity does not play a significant role in the incidence of maternal screenings that require hospitalization. The coefficients generally have the expected negative sign, but they are not statistically different from zero. An increase in travel expenditures for patients is likely, but there is no change in the decision to obtain the screening. However, these results could be explained by the consideration that although we expect low patient mobility for maternal screenings, it might not be equal to zero. Hence, the nearest hospital could be substituted by other hospitals. Women might have local preferences that induce them to prefer a hospital different from the closest one (e.g., based on others' or their own positive past experience with a different hospital).

Table B1: Descriptive Statistics

\begin{tabular}{|c|c|c|c|c|c|}
\hline Variable & $\begin{array}{l}\text { All } \\
(1) \\
\end{array}$ & $\begin{array}{c}\text { No Hosp } \\
+ \text { Pop1971<50,000 } \\
(2) \\
\end{array}$ & $\begin{array}{c}\text { Pop1971 }<25,000 \\
+ \text { Pop1971 }<25,000 \\
(3) \\
\end{array}$ & $\begin{array}{c}\text { Pop1971 }<25,000 \\
+ \text { Nearest }<50,000 \\
(4) \\
\end{array}$ & $\begin{array}{c}\text { Pop1971 }<25,000 \\
+ \text { Nearest }<50,000 \\
+ \text { No Hosp } \\
(5) \\
\end{array}$ \\
\hline Screenings & $\begin{array}{l}0.0079228 \\
(0.031055)\end{array}$ & $\begin{array}{c}0.0076385 \\
(0.0310732)\end{array}$ & $\begin{array}{c}0.0077379 \\
(0.0307929)\end{array}$ & $\begin{array}{c}0.0075355 \\
(0.0307969)\end{array}$ & $\begin{array}{c}0.0074063 \\
(0.0309718)\end{array}$ \\
\hline $\begin{array}{l}\text { Routine } \\
\text { Screenings }\end{array}$ & $\begin{array}{c}0.0011298 \\
(0.0110468)\end{array}$ & $\begin{array}{c}0.0011272 \\
(0.0113469)\end{array}$ & $\begin{array}{c}0.0011368 \\
(0.0111755)\end{array}$ & $\begin{array}{c}0.0011984 \\
(0.0127337)\end{array}$ & $\begin{array}{c}0.0012077 \\
(0.0129833)\end{array}$ \\
\hline Married & $\begin{array}{c}0.6578764 \\
(0.2303295)\end{array}$ & $\begin{array}{c}0.6611439 \\
(0.2309981)\end{array}$ & $\begin{array}{c}0.6585785 \\
(0.2311762)\end{array}$ & $\begin{array}{c}0.6654186 \\
(0.2289497)\end{array}$ & $\begin{array}{c}0.6681723 \\
(0.2282898)\end{array}$ \\
\hline Italian & $\begin{array}{c}0.9008522 \\
(0.1053647)\end{array}$ & $\begin{array}{c}0.9012413 \\
(0.1071127)\end{array}$ & $\begin{array}{c}0.9008446 \\
(0.1061947)\end{array}$ & $\begin{array}{c}0.9100985 \\
(0.1012094)\end{array}$ & $\begin{array}{c}0.9103366 \\
(0.1023085)\end{array}$ \\
\hline Age & $\begin{array}{c}32.41571 \\
(1.9042)\end{array}$ & $\begin{array}{c}32.3972 \\
(1.967011)\end{array}$ & $\begin{array}{c}32.40754 \\
(1.928084)\end{array}$ & $\begin{array}{l}32.3852 \\
(1.9526)\end{array}$ & $\begin{array}{c}32.37706 \\
(1.996414)\end{array}$ \\
\hline Observations & 69,482 & 62,139 & 66,593 & 36,861 & 34,056 \\
\hline Municipalities & 7,741 & 7,003 & 7,451 & 4,148 & 3,865 \\
\hline
\end{tabular}

Notes: Distance and Distance 1971 are in kilometers. Income is in per capita 2012 euros. Age is the average age of pregnant women. The higher number of municipalities observed in each subsample results from the lower number of missing observations in the data on screenings. 
Table B2: Results: Maternal Screenings

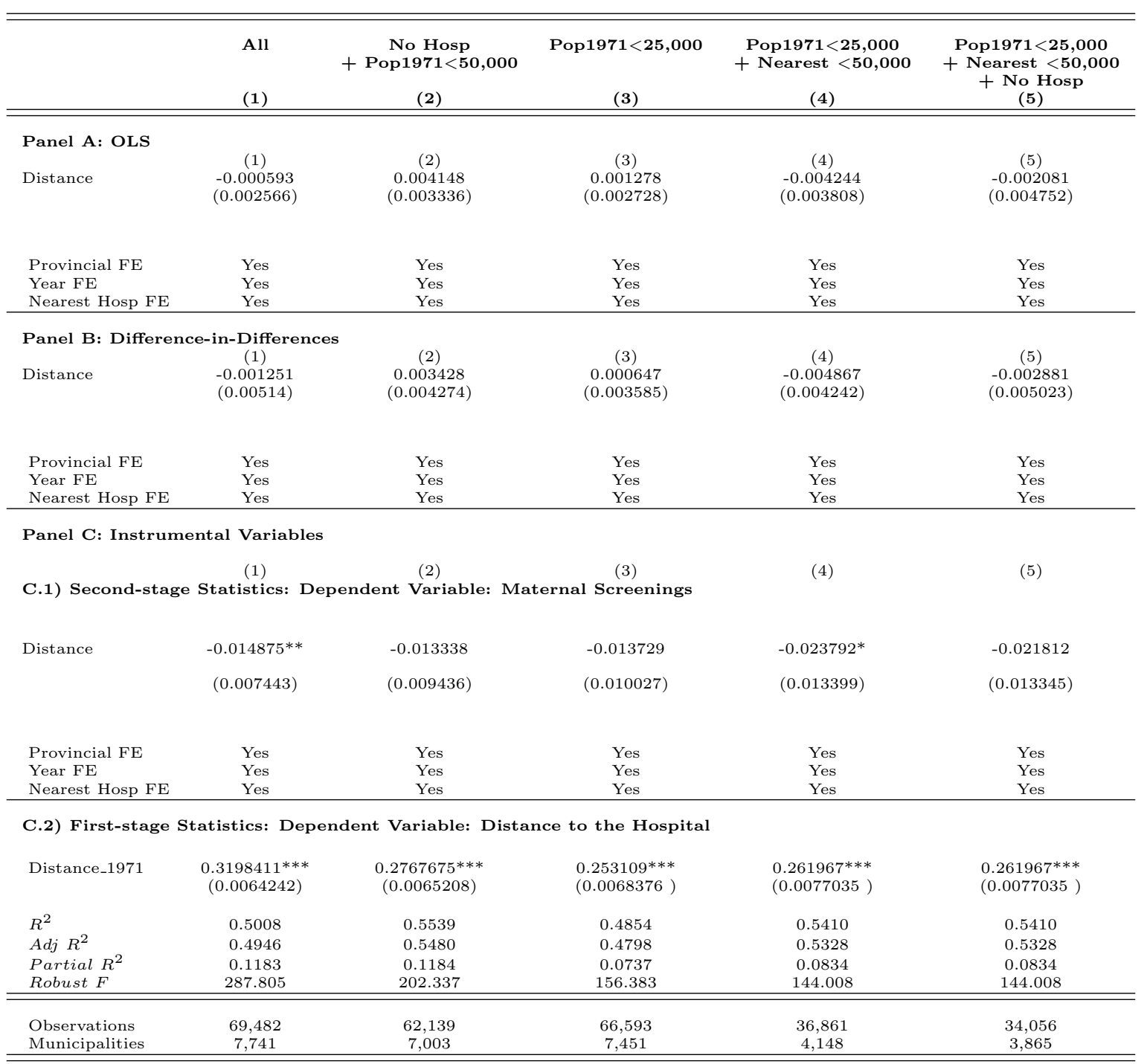

Notes: All coefficients and standard errors in Panel A, Panel B, and Panel C.1 are multiplied by 100. Every model and specification include controls for Population density, Income, Coastal, the dummies for altitude, Married, Italian, and Age. Significance at the $10 \%$ level is represented by *, at the $5 \%$ level by **, and at the $1 \%$ level by $* * *$. 
Table B3:Results: Routine Maternal Screenings

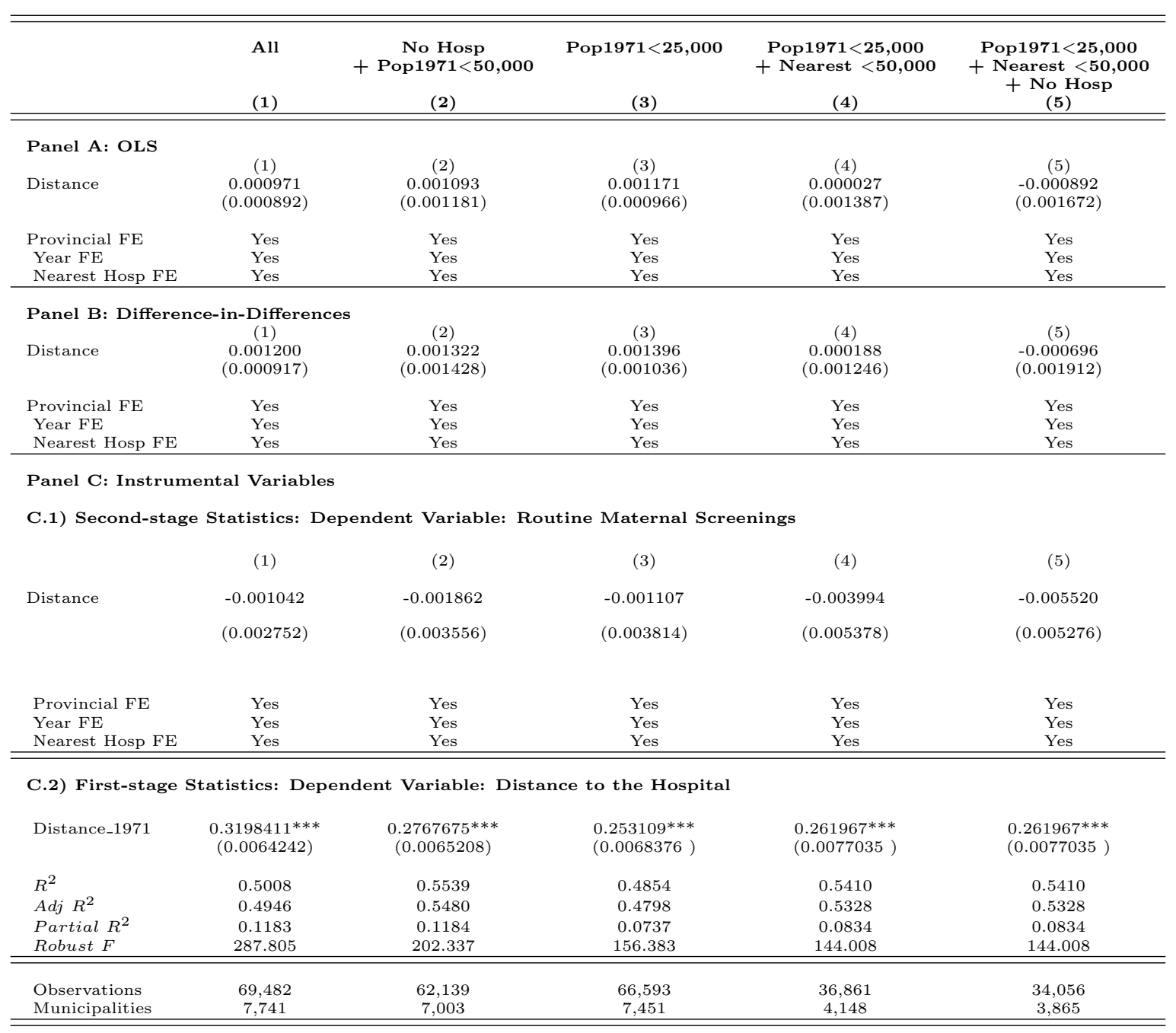

Notes: All coefficients and standard errors of Panel A, Panel B, and Panel C.1 are multiplied by 100 . Every model and specification include controls for Population density, Income, Coastal, the dummies for altitude, Married, Italian, and Age. Significance at the $10 \%$ level is represented by *, at the $5 \%$ level by **, and at the $1 \%$ level by ***. 


\begin{abstract}
Abstrakt
Tato studie zkoumá efekt blízkosti nemocnic za použití exogenní variace ve vzdálenosti od měst, která mají nemocnice na základě své velikosti. Naše instrumentální odhady používají komunální italská data a ukazují, že zvýšení vzdálenosti pacienta od nemocnice o jednu standardní odchylku (5 km) zvyšuje úmrtnost v průměru o 13.84\%. Tento odhad je ekvivalentní zvýšení o 0.92 úmrtí na 100 nehod. Dále ukazujeme, že OLS a DD odhady, běžně používané v literatuře, jsou vychýlené směrem dolů relativně ke skutečnému dopadu blízkosti od nemocnic, protože neadekvátně pracují s endogenním prostorovým rozmístěním potenciálních pacientů. Blízkost nemocnic je důležitější, čím více jsou nebezpečné vozovky, čím méně pohotová je záchranná služba, a čím nižší je kvalita nejbližší dostupné nemocnice.
\end{abstract}




\section{Working Paper Series}

ISSN 1211-3298

Registration No. (Ministry of Culture): E 19443

Individual researchers, as well as the on-line and printed versions of the CERGE-EI Working Papers (including their dissemination) were supported from institutional support RVO 67985998 from Economics Institute of the ASCR, v. v. i.

Specific research support and/or other grants the researchers/publications benefited from are acknowledged at the beginning of the Paper.

(c) Paola Bertoli and Veronica Grembi, 2016

All rights reserved. No part of this publication may be reproduced, stored in a retrieval system or transmitted in any form or by any means, electronic, mechanical or photocopying, recording, or otherwise without the prior permission of the publisher.

Published by

Charles University in Prague, Center for Economic Research and Graduate Education (CERGE) and

Economics Institute of the CAS, v. v. i. (EI)

CERGE-EI, Politických vězňů 7, 11121 Prague 1, tel.: +420 224005 153, Czech Republic.

Printed by CERGE-EI, Prague

Subscription: CERGE-EI homepage: http://www.cerge-ei.cz

Phone: + 420224005153

Email: office@cerge-ei.cz

Web: http://www.cerge-ei.cz

Editor: Jan Zápal

The paper is available online at http://www.cerge-ei.cz/publications/working_papers/.

ISBN 978-80-7343-372-7 (Univerzita Karlova v Praze, Centrum pro ekonomický výzkum a doktorské studium)

ISBN 978-80-7344-378-8 (Národohospodářský ústav AV ČR, v. v. i.) 
CERGE-EI

P.O.BOX 882

Politických vězňů 7

11121 Praha 1

Czech Republic http://www.cerge-ei.cz 